\title{
2012s-19 \\ Exchange Rate Fluctuations and Labour Market Adjustments in Canadian Manufacturing Industries
}

\author{
Gabriel Bruneau, Kevin Moran
}

Série Scientifique
Scientific Series

\author{
Montréal \\ Juin 2012
}

(C) 2012 Gabriel Bruneau, Kevin Moran. Tous droits réservés. All rights reserved. Reproduction partielle permise avec citation du document source, incluant la notice (C).

Short sections may be quoted without explicit permission, if full credit, including $@$ notice, is given to the source.
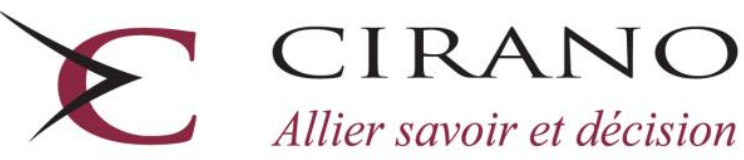

Allier savoir et décision

Centre interuniversitaire de recherche en analyse des organisations 


\section{CIRANO}

Le CIRANO est un organisme sans but lucratif constitué en vertu de la Loi des compagnies du Québec. Le financement de son infrastructure et de ses activités de recherche provient des cotisations de ses organisations-membres, d'une subvention d'infrastructure du Ministère du Développement économique et régional et de la Recherche, de même que des subventions et mandats obtenus par ses équipes de recherche.

CIRANO is a private non-profit organization incorporated under the Québec Companies Act. Its infrastructure and research activities are funded through fees paid by member organizations, an infrastructure grant from the Ministère du Développement économique et régional et de la Recherche, and grants and research mandates obtained by its research teams.

\section{Les partenaires du CIRANO}

\section{Partenaire majeur}

Ministère du Développement économique, de l'Innovation et de l'Exportation

\section{Partenaires corporatifs}

Autorité des marchés financiers

Banque de développement du Canada

Banque du Canada

Banque Laurentienne du Canada

Banque Nationale du Canada

Banque Royale du Canada

Banque Scotia

Bell Canada

BMO Groupe financier

Caisse de dépôt et placement du Québec

Fédération des caisses Desjardins du Québec

Financière Sun Life, Québec

Gaz Métro

Hydro-Québec

Industrie Canada

Investissements PSP

Ministère des Finances du Québec

Power Corporation du Canada

Rio Tinto Alcan

State Street Global Advisors

Transat A.T.

Ville de Montréal

\section{Partenaires universitaires}

École Polytechnique de Montréal

HEC Montréal

McGill University

Université Concordia

Université de Montréal

Université de Sherbrooke

Université du Québec

Université du Québec à Montréal

Université Laval

Le CIRANO collabore avec de nombreux centres et chaires de recherche universitaires dont on peut consulter la liste sur son site web.

Les cahiers de la série scientifique (CS) visent à rendre accessibles des résultats de recherche effectuée au CIRANO afin de susciter échanges et commentaires. Ces cahiers sont écrits dans le style des publications scientifiques. Les idées et les opinions émises sont sous l'unique responsabilité des auteurs et ne représentent pas nécessairement les positions du CIRANO ou de ses partenaires.

This paper presents research carried out at CIRANO and aims at encouraging discussion and comment. The observations and viewpoints expressed are the sole responsibility of the authors. They do not necessarily represent positions of CIRANO or its partners. 


\title{
Exchange Rate Fluctuations and Labour Market Adjustments in Canadian Manufacturing Industries
}

\author{
Gabriel Bruneau ${ }^{\dagger}$, Kevin Moran
}

\begin{abstract}
Résumé / Abstract
We estimate the impact of exchange rate fluctuations and other external factors on hours worked and employment in Canada's manufacturing industries. The analysis is based on a dynamic model of labour demand and the econometric strategy employs a dynamic OLS approach for cointegrating regressions. Our data is drawn from a panel of 20 manufacturing industries, from Statistics Canada's KLEMS database, and covers a long sample that includes two full cycles of appreciation and depreciation in the value of the Canadian dollar. We find that exchange rate fluctuations have economically and statistically significant effects on the labour choices of Canada's manufacturing employers, and that these effects are stronger for industries more exposed to trade. In addition, we find that the enactment of NAFTA in 1994 has had a negative impact on labour in manufacturing industries. Finally, we report that employment reacts faster than total hours worked, suggesting that hours worked per employee react in a countercyclical fashion to exchange rate fluctuations.
\end{abstract}

Mots clés/Keywords : exchange rate fluctuations, manufacturing employment, panel data estimation, cointegrating regression

Codes JEL : E24, F16, F31, J23

\footnotetext{
* The authors would like to thank Benoît Carmichael, Natalya Dygalo, Marc Henry, Lynda Khalaf, Benoît Perron and participants at the annual meeting of the Canadian Economics Association Conference and at the Journées d'économie appliquée GREEN-CIRPÉE for useful comments and discussions.

${ }^{\dagger}$ Département de sciences économiques, Université de Montréal, Montréal. Email: gabriel.bruneau@umontreal.ca (corresponding author).

¥Département d'économique, Université Laval, Québec. Email: kmoran@ecn.ulaval.ca.
} 


\section{Introduction}

Interest in the effects of exchange rate fluctuations on Canada's manufacturing industries has increased recently, following the sharp appreciation of the Canadian dollar relative to its U.S. counterpart. The labour input responses to this appreciation have generated particular attention, as concerns emerged that the higher value of the Canadian dollar would cause protracted declines in manufacturing employment.

Figure 1 illustrates these concerns, by suggesting there exists a link between the real exchange rate and total hours worked (top panel) and employment (bottom panel) in Canada's manufacturing sector. The figure shows that the Canadian dollar has experienced two full cycles of depreciation and appreciation in the last 30 years. These appear to have been closely reflected, possibly with a lag, into similar cycles in total hours worked and employment in manufacturing industries.

This paper provides a quantitative analysis of the link between exchange rate fluctuations and adjustments in the manufacturing industry's labour market. Specifically, we ask the following questions. How significant, and how persistent, are labour market adjustments to fluctuations in the value of the dollar? Are the adjustments industry-specific, being stronger for industries more exposed to trade? Are there composition effects between high- and lowskilled workers in the impact of exchange rate movements? To address these questions, the paper formulates a dynamic labour demand model and estimates it using KLEMS, an industry-level, panel database organized under the North-American Industry Classification System. The data cover the period 1976-2005 and thus contain the two complete cycles of depreciation and appreciation experienced by Canada's currency over the last 30 years.

We report four main findings. First, exchange rate fluctuations have sizeable effects on hours worked and employment in Canada's manufacturing industries. Under our preferred model specification, a 10-percent real appreciation of the Canadian dollar leads to a reduction of $7 \%$ in hours worked, while the effect is slightly smaller for employment, whose decline is just under $6 \%$. Second, these adjustments occur relatively rapidly, with around $40 \%$ of the gap between realized and targeted labour closed every period. Interestingly, we find that

adjustment is faster for employment, suggesting that hours worked per employee react to exchange rate fluctuations with a countercyclical pattern. Third, these effects are stronger 


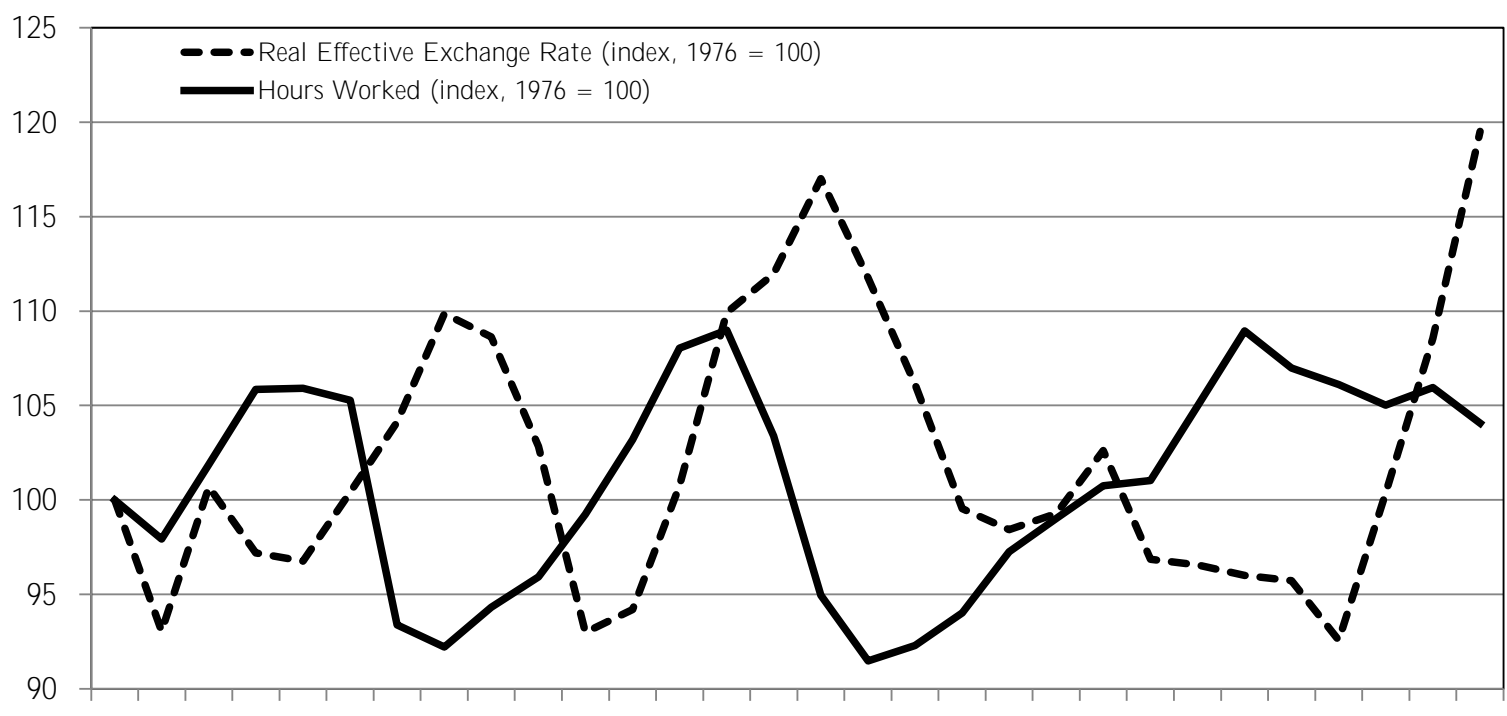

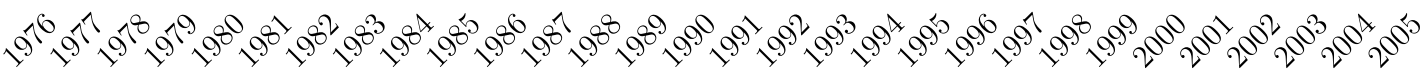

(a)

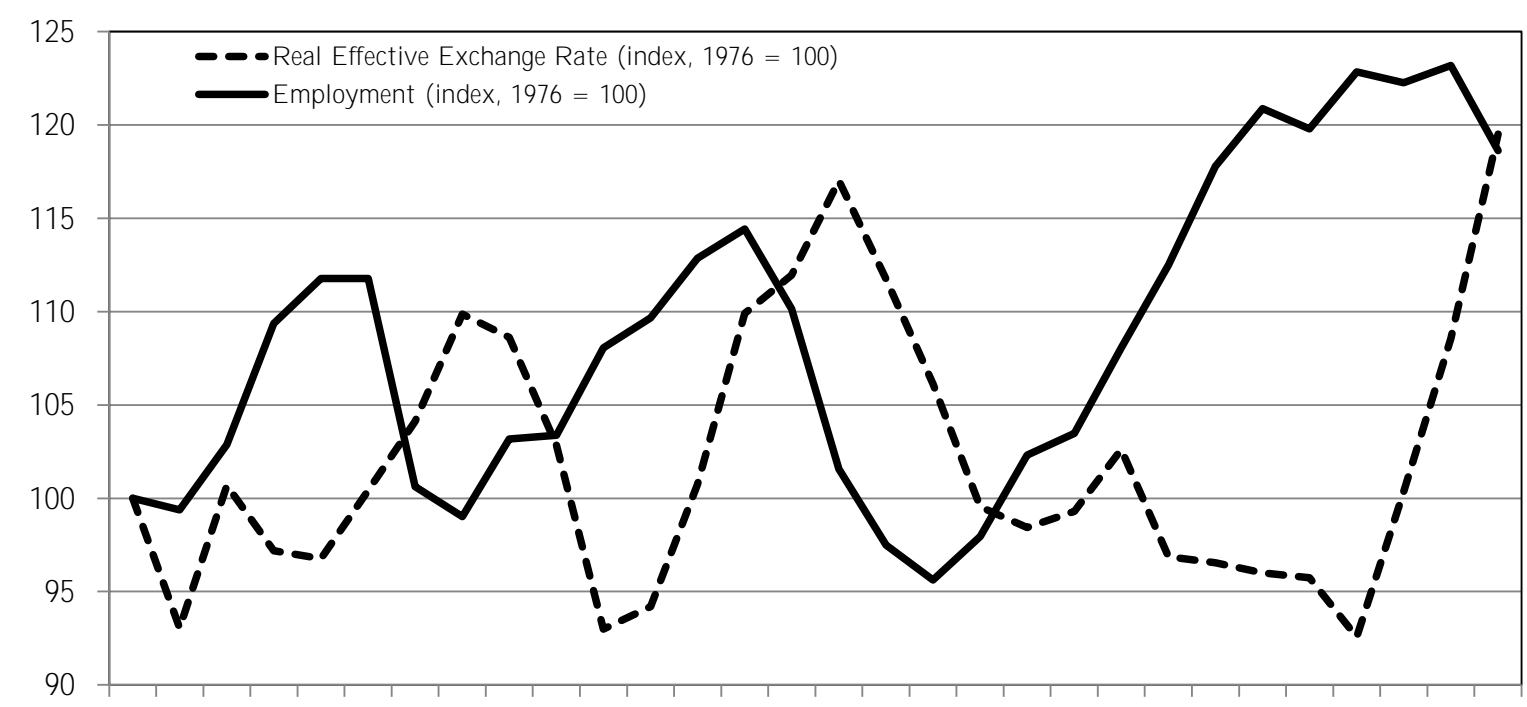

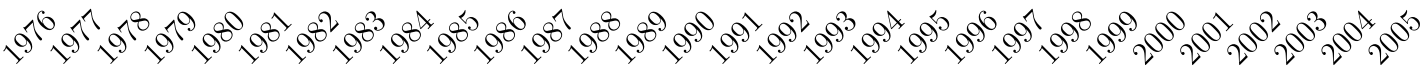

(b)

Figure 1: Real Effective Exchange Rate versus Hours Worked (panel (a)) and Employment (panel (b)), All Manufacturing Industries, from 1976 to 2005. 
for industries with a high exposure to international trade. Fourth, we find no evidence that exchange rate shocks have differentiated impacts on high- and low-skilled workers.

Previous evidence about the effects of exchange rate fluctuations on labour markets is mixed. Campa and Goldberg (2001), studying the adjustments of U.S. manufacturing firms to fluctuations of the U.S. dollar, find no significant impact on employment and hours worked. By contrast, Dekle (1998) reports significant effects on Japanese manufacturing employment following changes in the external value of the yen. Burgess and Knetter (1998), studying a cross-section of industrialized countries, show that exchange rate fluctuations have very small impacts on manufacturing employment in some countries like Germany and France, but significant ones in others, including the United States, Canada and the UK.

Canada's position as a small, highly open economy makes it an ideal case study for the impact of exchange rate fluctuations on manufacturing employment and our results suggest that these impacts can be very sizeable and occur rapidly. Earlier work concentrating on Canada appears in Leung and Yuen (2007). Our paper extends and generalizes their contribution by employing a longer dataset containing the recent appreciating cycle of the Canadian currency and considering the impact of exchange rate fluctuations on employment as well as hours worked. ${ }^{1}$ Interestingly, we report smaller impacts from exchange rate fluctuations than those estimated by Leung and Yuen (2007) but quicker adjustment. A possible interpretation of this contrast is that since our sample covers the recent phase of rapidly appreciating exchange rates, firms may have quickened their labour input adjustments because they felt the signal coming from the real exchange rate was clear.

This reminder of the paper is organized as follows. Section 2 presents the theoretical model and the empirical specification. Section 3 introduces the data employed in the estimation, which is drawn from the most recent release of the KLEMS database. Section 4 discusses estimation issues and our econometric strategy, while Section 5 reports our estimation results. Section 6 discusses our results and concludes. A detailed description of all data used and industry classification is provided in the Appendices.

\footnotetext{
${ }^{1}$ In addition, the present paper innovates on Leung and Yuen (2007) by employing an econometric strategy that allows for integrated variables and cointegration. Finally, our data comes from a new release of industryspecific data that is organized under the NAICS rather than the SIC (Standard Industrial Classification).
} 


\section{Model}

This section develops an econometric framework to analyze the impact of exchange rate fluctuations on the labour demand of Canadian manufacturing firms. Consider a representative firm in industry $i$, which sells its output both in domestic and foreign markets. Worldwide demand for its product can be written as

$$
y_{i, t}^{d}=a_{i, t} p_{i, t}^{-\theta}
$$

where $p_{i, t}$ is the price of the good (in Canadian dollars), $\theta$ is the price elasticity of demand, and $a_{i, t}$ indexes overall demand for the good. Below, we specify that $a_{i, t}$ depends on the exchange rate, which affects the firm's foreign currency price, and on aggregate economic activity, both domestic and foreign. We also allow trade agreements to produce shifts in $a_{i, t}$.

The production function for firm $i$ is

$$
y_{i, t}=F\left(L_{i, t}, Z_{i, t}\right)
$$

where $L_{i, t}$ is labour input and $Z_{i, t}$ is a vector containing all other production inputs. Denote the price of labour in industry $i$ by $w_{i, t}$ and collect the price of all other production inputs in the vector $p_{i, t}^{Z}$. Further, assume that each firm faces quadratic adjustment costs when changing its labour input. The profit maximizing problem of firm $i$ is therefore

$$
\max _{\left\{L_{i, t}, Z_{i, t}\right\}} E_{0} \sum_{t=0}^{\infty} \delta^{t}\left[p_{i, t} y_{i, t}-w_{i, t} L_{i, t}-p_{i, t}^{Z} Z_{i, t}-w_{i, t} \frac{b}{2}\left(L_{i, t}-L_{i, t-1}\right)^{2}\right],
$$

subject to (1) and (2), where $\delta$ is the discount factor applied to future dividends and $b$ indexes the severity of the adjustment costs. The system (1)-(3) is developed and discussed in detail in Nickell (1987). A large literature has used this framework to study the dynamic adjustment of labour to exchange rate shocks (Burgess and Knetter, 1998; Dekle, 1998; Campa and Goldberg, 2001; Leung and Yuen, 2007).

Nickell (1987) shows that the solution of (3) is characterized by a second-order difference equation whose stable root $\mu$ increases with the severity of adjustment costs. Further, he 
shows that a first-order approximation of the solution yields the following partial-adjustment process:

$$
\ln L_{i, t}=\mu \ln L_{i, t-1}+(1-\mu)(1-\delta g \mu) E_{t}\left[\sum_{\tau=0}^{\infty}(\delta g \mu)^{\tau} \ln L_{i, t+\tau}^{*}\right],
$$

where $g$ is the secular growth rate in real wages and $L_{i, t}^{*}$ is the frictionless $(b=0)$ labour demand. ${ }^{2}$ As expressed by (4), labour demand for firm $i$ follows a partial adjustment process towards a target equal to a geometric sum of future expected values of $L_{i, t}^{*}$, with the speed of adjustment depending on the severity of the adjustment costs through the root $\mu$.

Assuming that the production function in (2) is Cobb-Douglas, frictionless labour demand $L_{i, t}^{*}$ has the following simple form:

$$
\ln L_{i, t}^{*}=\alpha_{i, 0}+\alpha_{1} \ln w_{i, t}+\alpha_{2} \ln p_{i, t}^{Z}+\alpha_{3} \ln a_{i, t}
$$

with $\alpha_{1}<0$ the own-price elasticity. Notice that this specification allows for industryspecific fixed effects, represented by the heterogeneity in the constant term $\alpha_{i, 0}$.

Together, (4) and (5) express labour demand. If, in addition, movements in the variables affecting $L_{i, t}^{*}$ are largely permanent, the expectation operator in (4) greatly simplifies, so that we can write

$$
\ln L_{i, t}=\mu \ln L_{i, t-1}+(1-\mu) \ln L_{i, t}^{*}
$$

in which case (4) and (5) together yield the following:

$$
\ln L_{i, t}=\alpha_{i, 0}(1-\mu)+\mu \ln L_{i, t-1}+\alpha_{1}(1-\mu) \ln w_{i, t}+\alpha_{2}(1-\mu) \ln p_{i, t}^{Z}+\alpha_{3}(1-\mu) \ln a_{i, t} .
$$

Recall that $a_{i, t}$ indexes how aggregate economic conditions affect the demand faced by domestic producers. We specify that $a_{i, t}$ depends on world demand for Canadian goods, a variable we construct using Canadian GDP and the trade-weighted GDPs of Canada's trading partners and that we denote $Y_{t}{ }^{3}$ Next, $a_{i, t}$ depends on the real effective exchange

\footnotetext{
${ }^{2}$ Nickell also shows that aggregation issues resulting from the presence of two or more types of differentiated labour within the industry imply that additional lags of the dependent variable $L_{i, t}$ should be included in (4). Our empirical work accounts for this possibility.

${ }^{3}$ See Appendix A for details about the construction of this variable. We found that this measure efficiently aggregates demand from domestic and foreign GDPs. Our results are robust to alternative specifications using separate influences of Canadian and US GDPs, or using different proxies for activity (final domestic demand, industrial production, import penetration measures, etc.).
} 
rate $\left(s_{t}\right)$. Further, we include dummy variables that signal the enactment of the CanadaU.S. Free-Trade Agreement $\left(C U S F T A_{t}\right)$ and the North-American Free-Trade Agreement $\left(N A F T A_{t}\right)$, to allow shifts in the structure of Canadian manufacturing that might have been induced by these agreements. In addition, we include industry-specific time trends, to account for structural changes unrelated to trade agreements. Recapping, the evolution of $a_{i, t}$ obeys:

$$
\ln a_{i, t}=\varphi_{i, 0} \cdot t+\varphi_{1} \ln s_{t}+\varphi_{2} \ln Y_{t}+\varphi_{3} C U S F T A_{t}+\varphi_{4} N A F T A_{t} .
$$

Finally, in our empirical work, the price-vector for inputs other than labour, $p_{i, t}^{Z}$, includes the price of capital $\left(p_{i, t}^{K}\right)$ and the price of intermediate inputs $\left(p_{i, t}^{I I}\right)$. Our robustness analysis also studies whether decomposing this last variable into separate components for the price of energy $\left(p_{i, t}^{E}\right)$, the price of materials $\left(p_{i, t}^{M}\right)$, and the price of services $\left(p_{i, t}^{S}\right)$ affects our results. Our complete benchmark specification for the labour input of industry $i$ at time $t$ is thus as follows:

$$
\begin{aligned}
\ln L_{i, t}= & \gamma_{i, 0}+\gamma_{i, 1} \cdot t+\gamma_{2} \ln L_{i, t-1}+\gamma_{3} \ln w_{i, t}+\gamma_{4} \ln p_{i, t}^{K}+\gamma_{5} \ln p_{i, t}^{I I}+ \\
& \gamma_{6} \ln s_{t}+\gamma_{7} \ln Y_{t}+\gamma_{8} C U S F T A_{t}+\gamma_{9} N A F T A_{t}+\epsilon_{i, t},
\end{aligned}
$$

where $\gamma_{i, 0}$ to $\gamma_{9}$ are simple transformations of the original parameters (note for example that $\gamma_{2}$ is simply the speed of adjustment $\mu$ ). In expression (9), fluctuations in the real exchange rate can affect labour input through the work of two channels: first, a direct (demand) effect that arises because exchange rate fluctuations affect the demand of trade-oriented firms (the parameter $\gamma_{6}$ ); second, an indirect effect that arises if one of the production input is imported, so that real exchange rate fluctuations affect its relative price and thus also labour demand through a substitution channel. Such an effect is most likely to be sizeable for Canadian manufacturing firms in the case of the capital input.

\section{Data}

To estimate equation (9), we construct a balanced panel of annual data for the Canadian manufacturing sector. The database includes both industry-specific and aggregate data and covers the period from 1976 to 2005. 
The industry-specific data are from the KLEMS database and the Labour Force Survey. KLEMS, from Statistics Canada's Canadian Productivity Accounts, provides annual data on prices and quantities for output, as well as for capital, labour, energy, material, and service inputs for all Canadian industries. As noted above, our benchmark specification uses the intermediate inputs measure, a weighted sum of the energy, material and service inputs, but we test the robustness of our results to this aggregation. The database has been reorganized under the NAICS classification and the data we use are from the 20 manufacturing industries, at the 3-digit industry level. Specifically, KLEMS provides us with data for labour input $L_{i, t}$, hours worked $H_{i, t}$, the relative price of labour $w_{i, t}$, the relative user cost of capital $p_{i, t}^{K}$, the relative price of intermediate inputs $p_{i, t}^{I I}$ (a weighted average of relative prices of energy, materials and services), the relative price of energy $p_{i, t}^{E}$, the relative price of materials $p_{i, t}^{M}$ and, finally, the relative price of services $p_{i, t}^{S}$, for all industries $i=1,20$. A complete description of these variables is provided in Appendix A.

Our empirical analysis estimates (9) for three alternative measures of the labour input. First, two measures of labour are recovered from KLEMS: hours worked $H_{i, t}$ and overall labour input $L_{i, t}$. The variable $H_{i, t}$ represents a simple-sum of the hours worked for all workers in industry $i$; by contrast, $L_{i, t}$ provides a quality-weighted sum of hours, controlling for education and experience of the workers. ${ }^{4}$ Such a distinction is potentially important if composition effects in overall labour are triggered by exchange rate fluctuations. Our third measure for labour input is employment $E_{i, t}$, recovered from the Labour Force Survey. We include $E_{i, t}$ to analyze the effect of exchange rate fluctuations on the number of jobs, without any other considerations (i.e. full- or part-time, age, skills, education, etc.). Using three different measures of labour can potentially help identify impacts that exchange rate fluctuations might have on the labour market structure or to composition of the labour force across different classes of workers.

The real exchange rate, $s_{t}$, is the Canadian dollar effective exchange rate index, deflated by normalized unit labour costs (NULC). In this measure, nominal exchange rates with Canada's trading partners are weighted by their share in Canada's international trade, and nominal rates are then deflated by unit labour costs in each partner countries to capture Canada's ability to sell abroad profitably. ${ }^{5}$ As written, an increase in $s_{t}$ corresponds to a

\footnotetext{
${ }^{4}$ See Appendix A for more details about the construction of $L_{i, t}$.

${ }^{5}$ This follows IMF standards for constructing real effective exchange rates. Lafrance, Osakwe, and St-
} 
real appreciation of the Canadian dollar.

We construct our measure of world demand for Canadian manufacturing goods, $Y_{t}$, by summing up real Canadian GDP and the real trade-weighted GDPs of Canada's trading partners, where the weights reflect the share of each partner in Canada's international trade. Finally, the trade agreement dummies, CUSFT $A_{t}$ and $N A F T A_{t}$, take the value 1 starting in 1989 and 1994, respectively.

The impact of exchange rate fluctuations on the labour input of an industry should in principle depend on its openness to trade, both to exports (so that a depreciation facilitates selling in foreign markets) and to imports (as the same depreciation reduces the competitiveness of foreign producers in domestic markets). To allow for this possibility, our empirical analysis estimates (9) separately for industries with high and low trade exposure. To measure trade exposure, we follow Dion (2000) and define the net trade exposure (NTE) of an industry as follows: exports as a share of production, less imported output as a share of production, plus competing imports as a share of the domestic market. We compute a measure of NTE for all the manufacturing industries using the 2000 input-output tables. Industries with NTE above the manufacturing sector average are classified as high-NTE, while below-average industries are classified as low-NTE. Table 12 in Appendix B presents the resulting classification of the 20 manufacturing industries we study.

\section{Econometric Methodology}

\section{Panel Data Estimation}

The recent popularity of panel data estimation arises in large part from the robustness it provides relative to pure time-series models. For example, while undetected unit-root behavior can lead to spurious inference in pure times-series models, regression estimates in panel datasets remain consistent because the information contained in the independent cross-section dimension of the data leads to a stronger overall signal than in pure time-series cases (Kao, 1999; Phillips and Moon, 2000).

However, correctly assessing the order of integration of variables remains important in order

Amant (1998) argue that using unit labour costs to deflate exchange rates is the adequate method to fully capture their impact on the Canadian economy. Our main empirical results are robust to alternative deflators for the nominal exchange rates, such as relative CPIs. 
to conduct inference, because the asymptotic distribution of panel estimators in the presence of unit roots is non-standard and the classic $t$-test statistic diverges at the same rate as in time-series. Moreover, if the data are cointegrated in addition to containing unit roots, the panel regression estimates, while still consistent, again follow non-standard distributions. Indeed, even if the OLS estimators of the cointegrated vectors are super-consistent, their distribution is asymptotically biased and depends on the nuisance parameters associated with the presence of serial correlation in the data (Kao and Chen, 1995; Pedroni, 1996; Kao and Chiang, 1999).

The two most popular techniques to analyze systems of cointegrated variables are the Fully Modified Ordinary Least Squares (FMOLS), initially proposed by Phillips and Hansen (1990), and the Dynamic Ordinary Least Squares (DOLS) introduced by Saikkonen (1991) and Stock and Watson (1993). Subsequent studies (Pedroni, 1996; Kao and Chiang, 1999; Phillips and Moon, 2000) show that these two techniques, when applied to panel data, lead to unbiased estimators with standard normal distributions. Moreover, the results in Kao and Chiang (1999) suggest that DOLS is the superior method to estimate cointegration vectors in panel data with small samples. More recently, Mark and Sul (2002) reinforce this finding and show that panel data DOLS is fully parametric, computationally convenient and more precise than single equation estimators, while allowing for cross-units heterogeneity by the inclusion of individual-specific fixed effects and time trends. Our empirical analysis thus uses DOLS. Before describing our estimation, we first discuss preliminary tests conducted on the data to assess their cross-section dependence, unit root and cointegration characteristics.

\section{Cross-Section Dependence}

Heterogeneity poses a key challenge to panel data unit root and cointegration tests: can the same model be used to test the unit root hypothesis across all individual units (industries in our case) of the panel's cross-section? If not, the unit root tests employed need to take into account the industry-specific dynamics. ${ }^{6}$ We use the Pesaran (2004) test to ascertain the cross-section dependence (CSD) characteristics of our data, because this test has been shown to have good size and power for dynamic models with relatively small samples. The test is

\footnotetext{
${ }^{6}$ In certain cases, tests based on pooled estimates of the autoregressive parameters could be consistent against a heterogeneous alternative (Moon and Perron, 2004).
} 
based on the correlation among the residuals from a panel fixed-effect estimation of (9) and the null hypothesis is the absence of cross-section dependence. Results from applying this test to the three measures of the labour input $\left(L_{i, t}, H_{i, t}\right.$ and $\left.E_{i, t}\right)$ are presented in Table 1. The very low $p$-values reported in the table provide strong evidence against the null of cross-section independence. Our empirical analysis below thus allows for CSD.

\begin{tabular}{lcc}
\multicolumn{3}{c}{$\begin{array}{c}\text { Table 1: Cross-section } \\
\text { Independence Tests }\end{array}$} \\
\hline \hline Variables & Test Value $^{a}$ & $p$-value \\
\hline$L_{i, t}$ & 0.298 & 0.000 \\
$H_{i, t}$ & 0.306 & 0.000 \\
$E_{i, t}$ & 0.169 & 0.000 \\
\hline \hline
\end{tabular}

\footnotetext{
${ }^{a}$ The test statistic is the absolute value of the correlation in the residuals of a fixed-effects estimation of (9).
}

\section{Unit Root Tests}

Various solutions have been proposed to allow CSD in unit root tests. Rather than consider the correlation across units as nuisance parameters, these tests aim to exploit the co-movements in the variables to define new test statistics. One approach, exemplified by Pesaran (2007), relies on the factor structure. Like previous contributions, eg. Phillips and Sul (2003), Pesaran considers a one-factor model with heterogeneous loading factors for residuals, but instead of basing the unit root tests on deviations from the estimated common factors, his test supplements the standard individual Dickey-Fuller (DF) or Augmented Dickey-Fuller (ADF) regressions with the cross-section average of lagged levels and first-differences of the individual series. The test statistic is the mean of individual DF or ADF $t$-statistics of each unit in the panel, which delivers the CIPS statistic. ${ }^{7}$ The null hypothesis is that all series are non-stationary. A truncated version of the statistic, denoted CIPS $^{\star}$, is also considered by Pesaran and found to have desirable properties; our empirical analysis thus uses the CIPS $^{\star}$ test. $^{8}$

Results for panel unit roots tests are presented in Table 2 for each variable that had a

\footnotetext{
${ }^{7}$ The acronym refers to the fact that the CIPS is a cross-sectionally augmented version of the IPS test in Im, Pesaran, and Shin (2003).

${ }^{8}$ The CIPS ${ }^{\star}$ statistic has finite first and second-order moments. Under the null of non-stationarity, the asymptotic distribution of CIPS ${ }^{\star}$ exists, is free of nuisance parameters, and is exempt of size distortions in the case of models with residual serial correlations and linear trends. Finally, the CIPS ${ }^{\star}$ test is consistent under the alternative that only a fraction of the series are stationary. Simulated critical values of CIPS ${ }^{\star}$ for various sample size against the null hypothesis of non-stationarity are presented in Pesaran (2007).
} 
cross-section structure, namely $L_{i, t}, H_{i, t}, E_{i, t}, w_{i, t}, p_{i, t}^{K}, p_{i, t}^{I I}, p_{i, t}^{E}, p_{i, t}^{M}$, and $p_{i, t}^{S}$. The lag length is chosen with the modified Akaike criterion (Ng and Perron, 2001) with a maximum lag length of 8 lags for the computation of $\mathrm{ADF}$, in the first step, and taking the average of the individual optimal lag length for the CIPS ${ }^{\star}$, in the second step. For each variable, the test is first conducted with the variable in level (not rejecting $H_{0}$ thus suggest that the variable is $\mathrm{I}(1)$ ) and then in growth rate (rejecting $H_{0}$ now suggests the variable is $I(1)$ ). The table shows that for most variables, strong evidence of $I(1)$ behaviour exists, although results are less conclusive for the price of energy $p_{i, t}^{E}$. For completion, Table 3 provides the results of $\mathrm{ADF}$ unit root tests for the aggregate variables $s_{t}$ and $Y_{t}$, which don't have a cross-section structure. Again the presence of unit roots is strongly supported.

Table 2: Panel Unit Root Tests

\begin{tabular}{lccc}
\hline \hline Variables & \multicolumn{3}{c}{$p$-value of CIPS ${ }^{\star}$ Test $^{a}$} \\
\cline { 2 - 4 } & $\begin{array}{c}\text { No constant } \\
\text { No trend }\end{array}$ & $\begin{array}{c}\text { With constant } \\
\text { No trend }\end{array}$ & $\begin{array}{c}\text { With constant } \\
\text { With trend }\end{array}$ \\
\hline$L_{i, t}$ (level) & 0.615 & 0.990 & 0.810 \\
$L_{i, t}$ (first difference) & 0.170 & 0.010 & 0.085 \\
\hline$H_{i, t}$ (level) & 0.650 & 0.895 & 0.940 \\
$H_{i, t}$ (first difference) & 0.010 & 0.015 & 0.145 \\
\hline$E_{i, t}$ (level) & 0.905 & 0.990 & 0.990 \\
$E_{i, t}$ (first difference) & 0.080 & 0.010 & 0.010 \\
\hline$w_{i, t}$ (level) & 0.225 & 0.635 & 0.990 \\
$w_{i, t}$ (first difference) & 0.010 & 0.010 & 0.040 \\
\hline$p_{i, t}^{K}$ (level) & 0.425 & 0.515 & 0.815 \\
$p_{i, t}^{K}$ (first difference) & 0.010 & 0.010 & 0.010 \\
\hline$p_{i, t}^{I I}$ (level) & 0.120 & 0.110 & 0.560 \\
$p_{i, t}^{I I}$ (first difference) & 0.010 & 0.010 & 0.010 \\
\hline$p_{i, t}^{E}$ (level) & 0.165 & 0.950 & 0.765 \\
$p_{i, t}^{E}$ (first difference) & 0.010 & 0.010 & 0.930 \\
\hline$p_{i, t}^{M}$ (level) & 0.175 & 0.040 & 0.460 \\
$p_{i, t}^{M}$ (first difference) & 0.010 & 0.010 & 0.010 \\
\hline$p_{i, t}^{S}$ (level) & 0.415 & 0.855 & 0.795 \\
$p_{i, t}^{S}$ (first difference) & 0.010 & 0.010 & 0.010 \\
\hline \hline
\end{tabular}

${ }^{a}$ We use the truncated version of CIPS, CIPS ${ }^{\star}$. Therefore, the minimum $p$-value is 0.01 .

Table 3: Unit Root Tests for Aggregate Variables

\begin{tabular}{lccc}
\hline \hline Variables & \multicolumn{3}{c}{$p$-value of ADF Test } \\
\cline { 2 - 4 } & $\begin{array}{c}\text { No constant } \\
\text { No trend }\end{array}$ & $\begin{array}{c}\text { With constant } \\
\text { No trend }\end{array}$ & $\begin{array}{c}\text { With constant } \\
\text { With trend }\end{array}$ \\
\hline$s_{t}$ (level) & 0.855 & 0.045 & 0.170 \\
$s_{t}$ (first difference) & 0.010 & 0.010 & 0.050 \\
\hline$Y_{t}$ (level) & 0.990 & 0.875 & 0.395 \\
$Y_{t}$ (first difference) & 0.045 & 0.035 & 0.130 \\
\hline \hline
\end{tabular}

\section{Panel Cointegration Tests}

Like their unit root counterparts, the first generation of panel cointegration tests assumed that no cross-sectional dependence was present in the data. Testing for cointegration under 
CSD is the subject of an active literature, with two main solutions being suggested: first, modeling the linkages as the result of unobserved common factors, thus allowing them to be estimated by principal component methods and removed from the data so that simple procedures for independent panels can be applied; second, applying bootstrap algorithms to estimate the distribution of the statistic of interest conditional on the cross-section linkages. One bootstrapping approach is from Di Iorio and Fachin (2009), who extend the stationary bootstrap test (Politis and Romano, 1994; Parker, Paparoditis, and Politis, 2006) to the case of panel data cointegration and show that it delivers good size and power. ${ }^{9}$ This is the method we use.

We thus conduct 999 bootstrap replications of the Di Iorio and Fachin (2009) algorithm. This involve, first, estimating the relationship (9) via the within transformation to obtain estimates for the regression residuals $\epsilon_{i, t}$. Second, an $\mathrm{AR}(1)$ process for $\epsilon_{i, t}$ is estimated to obtain residuals $\nu_{i, t}$ and the autoregressive parameter $\rho_{i}$. In the presence of non-stationary regressand and regressors, the residuals should be non-stationary in absence of cointegration ( $\rho_{i}=1$ and a spurious regression) and stationary in the presence of cointegration $\left(\rho_{i}<1\right.$ and a cointegrating regression). Given the null hypothesis of no-cointegration in all units $\left(H_{0}: \rho_{i}=1\right.$ for $\left.i=1, \ldots, 20\right)$, we tested four different alternative hypotheses: $H_{1}: \rho_{i}<1$ in all units, $H_{1}: \rho_{i}<1$ in at least one units, $H_{1}: \rho_{i}<1$ in most of the units and $H_{1}: \rho_{i}<1$ in most of the units and $\rho_{i}<<1$ in a smaller number of units. The choice of alternative dictates the statistic $G$ used to summarize $\rho_{i}$ and are, respectively, $G=\operatorname{Max}\left(\rho_{i}\right)$, $G=\operatorname{Min}\left(\rho_{i}\right), G=\operatorname{Median}\left(\rho_{i}\right)$, and $G=\operatorname{Mean}\left(\rho_{i}\right) .{ }^{10}$ Table 4 presents the test results: significant statistical evidence in favour of cointegration is present in our panel, and our empirical analysis below thus will take this fact into account.

\footnotetext{
${ }^{9}$ Other bootstrapping approaches include Fachin (2007), who applies the continuous-path block bootstrap (Paparoditis and Politis, 2001, 2003) separately to the right- and the left-hand side variables to generate unrelated pseudoseries obeying the null hypothesis of no cointegration, and Westerlund and Edgerton (2007), who develop a sieve bootstrap procedure for testing the null of cointegration.

${ }^{10}$ Following Di Iorio and Fachin (2009), we resample the vector $\nu_{i, t} 999$ times with a stationary bootstrap scheme with a probability to start a new block $(p)$ chosen to get a average block length of 8 to generate pseudoresiduals with the null hypothesis of no-cointegration $\left(\rho_{i}=1\right)$ and pseudodata using the estimated parameters of the panel-within regression. The four test statistics are calculated for each bootstrap replication. We then obtain 999 pseudo- $G$ and 1 true $G$ for each of the four test statistics. We sorted these 1000 test statistics in ascending order and the $p$-value of the test is the position of the true $G$.
} 
Table 4: Residual-based Panel Cointegration Tests

\begin{tabular}{lcccc}
\hline \hline Variables & \multicolumn{4}{c}{$p$-value of the Di Iorio and Fachin (2009) test } \\
\cline { 2 - 5 } & $G=\operatorname{Max}\left(\rho_{i}\right)$ & $G=\operatorname{Min}\left(\rho_{i}\right)$ & $G=\operatorname{Median}\left(\rho_{i}\right)$ & $G=\operatorname{Mean}\left(\rho_{i}\right)$ \\
\hline$L_{i, t}$ & 0.001 & 0.001 & 0.001 & 0.001 \\
$H_{i, t}$ & 0.001 & 0.001 & 0.001 & 0.001 \\
$E_{i, t}$ & 0.004 & 0.001 & 0.001 & 0.001 \\
\hline \hline
\end{tabular}

\section{Estimation Method}

As a summary, the presence of cointegration among $I(1)$ variables leads us to choose the panel within DOLS approach advocated by Kao and Chiang (1999) and described in Mark and Sul (2002) to estimate equation (9). Statistical inference is then based on DriscollKraay-Newey-West standard errors (Driscoll and Kraay, 1998). To assess the robustness of our results, however, we used alternative estimation methods. To that end, we used the group-mean DOLS, the group-mean FMOLS, and bootstrap methods applied to both the panel DOLS and the group-mean FMOLS estimators to address the issues of distortion in small sample (i.e. bias correction) and asymptotic refinement (Li and Maddala, 1997; Li and Xiao, 2003; Chang, Park, and Song, 2006). ${ }^{11}$ The group-mean DOLS delivered highly inaccurate results, mainly due to the high number of regressors in each cross-section of the panel. The group-mean FMOLS and the bootstrap version of the panel within DOLS and the group-mean FMOLS delivered accurate results. The conclusion, compare to the panel within DOLS estimation, remained the same. However, the panel within DOLS outperformed all these methods in terms of loss functions, both mean absolute error and root mean squared error: we thus present the results from panel DOLS below.

\section{Results}

This section presents our estimation results using the panel within DOLS. All regressions are estimated in logs and include industry-specific time trends. In each table of results below, column (1) presents estimates for the benchmark version of equation (9). Next, columns (2) and (3) assess the robustness of this benchmark to the use of the lagged real exchange rate $\left(s_{t-1}\right)$, and its two-year moving average $\left(s_{t}^{m a}\right)$, respectively. Significant differences between these results can suggest that volatility in $s_{t}$ leads firms to wait for the exchange rate signal to be confirmed before adjusting their labour input. Column (4) adds the lagged value of the

\footnotetext{
${ }^{11}$ Pedroni (1996) shows that group-mean FMOLS delivered more accurate results than the panel within FMOLS in small sample, therefore we do not estimate the model using the latter technique.
} 
relative user cost of capital as an additional regressor, to verify whether the current value of the price of capital is sufficient to account for substitution effects between labour and capital. Column (5) assesses whether the benchmark results are affected by decomposing the price of intermediate inputs $p_{i, t}^{I I}$ into subcomponents for the price of energy $\left(p_{i, t}^{E}\right)$, the price of materials $\left(p_{i, t}^{M}\right)$, and the price of services $\left(p_{i, t}^{S}\right)$. Finally, column (6) adds one more lag of the labour input to the estimation, as Nickell (1987) suggests is necessary to address aggregation issues in the presence of differentiated labour types. In all tables, estimates superscripted by ${ }^{\star},{ }^{\star \star}$, or ${ }^{\star \star \star}$ indicate significance at the $10 \%, 5 \%$ and $1 \%$ levels, respectively, using Driscoll-Kraay-Newey-West standard errors (Driscoll and Kraay, 1998). The speed of adjustment is one minus the coefficient(s) on the lagged labour input, whereas the long-run elasticity is the coefficient on the real exchange rate divided by the speed of adjustment. Finally, the mean absolute error and the root mean squared error are measures of fit to assess the accuracy of the model in recursive prediction ${ }^{12}$ and the $R$-squared and adjusted$R$-squared are measures of fit to assess the accuracy of the estimated model.

\subsection{All Industries}

We first examine labour adjustment to exchange rate fluctuations using data from all manufacturing industries. Overall, results are statistically significant and of the expected signs. The own-price elasticity of labour is negative, while those for the price of capital and the price of intermediary inputs are positive, as expected by standard substitution effects. The response of labour to exchange rate is statistically and economically significant, while the speed of adjustment is relatively high. Importantly, the estimated impact of exchange rate fluctuations is more significant when the lagged exchange rate $\left(s_{t-1}\right)$ or its two-year moving average $\left(s_{t}^{m a}\right)$ is used, suggesting that firms wait for a clear signal to emerge from volatile

\footnotetext{
${ }^{12}$ The mean absolute error (MEA) is the (equal-weighted) average over the sample of the absolute value of the differences between prediction and the corresponding observation: the predicted value is generated recursively by the model for each year, the first year serving as the initial condition. We generate predicted labour for each cross-section separately, sum the absolute differences for each cross-section separately, sum for all cross-sections, and finally take the mean value by dividing by the total number of observations. The root mean squared error (RMSE) is the average over the sample of the squared value of the differences between prediction and the corresponding observation. It's a quadratic score, where large errors are weighted with a relatively higher weight. Again the predicted value is for each cross-section is generated separately and we then sum the squared differences for each cross-section separately, sum for all cross-sections, take the mean value by dividing by the total number of observations, and finally take the root. Both the MAE and RMSE can range from 0 to infinity. They are negatively-oriented scores: Lower values are better. Finally, the number of lags and leads included in the regression, in accordance with the DOLS method, have been chosen by the Akaike criterion, which always point to 1 lag and 1 lead.
} 
exchange rate movements. Higher global economic activity, as represented by $Y_{t}$, increases the use of labour inputs, as expected. Finally, the enactment of the Canada-U.S. FreeTrade Agreement $\left(C U S F T A_{t}\right)$ and especially the North-American Free-Trade Agreement $\left(N A F T A_{t}\right)$ appear to have had a significant negative impact on manufacturing employment. This result is compatible with earlier work (Gaston and Trefler, 1997; Beaulieu, 2000) reporting that trade liberalization has increased productivity but decreased employment in Canada's manufacturing industries.

Turning now to specific results, Table 5 reports estimates for the quality-adjusted labour input $L_{i, t}$. The benchmark estimation results in column (1) report a short-run elasticity of -0.1253 following exchange rate movements, while the corresponding long-run elasticity is -0.3354 . In other words, a 10-percent appreciation in the real exchange rate leads to a 1.25-percent decrease in $L_{i, t}$ in the short run and a 3.35-percent decrease in the long run. The estimated speed of adjustment is 0.3736 , which indicates that $37 \%$ of the gap between realized and targeted labour demand is closed every year. As previewed above, the sensitivity of $L_{i, t}$ to the exchange rate is significantly increased in columns (2) and (3), when the current value of the exchange rate is replaced by its lagged value and its two-year moving average, respectively: the short-run elasticities are increased to -0.2628 (column 2) and -0.3252 (column 3), respectively, while the long-run equivalents are now -0.6891 and -0.8989 . According to these results, a $10 \%$ depreciation could thus decrease the labour input by up to $9 \%$ in the long run. Note that using the lagged value of the exchange rate or its moving average does not modify noticeably the estimates for the speed of adjustment.

The coefficient on $w_{i, t}$, the relative price of labour, is significant and negative with a value of -0.1411 , while the coefficient on the relative user cost of capital $p_{i, t}^{K}$, at 0.0432 , indicates that capital and labour are substitutes. Since a significant proportion of the capital used by Canadian manufacturing firms is imported from abroad (mainly from the U.S.) an additional impact of exchange rate movements works through the price of capital: a real appreciation not only reduces the direct demand for labour inputs but, by making imported capital cheaper, also makes Canadian firms substitute away from labour and towards other inputs. 
Table 5: Estimation Results - Labour Input $L_{i, t}$ - All Industries

\begin{tabular}{|c|c|c|c|c|c|c|}
\hline \multirow[t]{2}{*}{ Regressors } & \multicolumn{6}{|c|}{ Specifications } \\
\hline & (1) & (2) & (3) & $(4)$ & (5) & $(6)$ \\
\hline \multirow[t]{2}{*}{$\ln L_{i, t-1}$} & $0.6264^{* * *}$ & $0.6186^{* * *}$ & $0.6382^{* * *}$ & $0.5692^{* * *}$ & $0.5285^{* * *}$ & $0.8151^{* * *}$ \\
\hline & $(0.0634)$ & $(0.0563)$ & $(0.0632)$ & $(0.0613)$ & $(0.0579)$ & $(0.0547)$ \\
\hline \multirow{2}{*}{$\ln L_{i, t-2}$} & - & - & - & - & - & $-0.2669^{* * *}$ \\
\hline & - & - & - & - & - & $(0.0355)$ \\
\hline \multirow[t]{2}{*}{$\ln w_{i, t}$} & $-0.1411^{* * *}$ & $-0.1032^{* * *}$ & $-0.1154^{* * *}$ & $-0.1187^{* * *}$ & $-0.0802^{*}$ & $-0.1018^{* * *}$ \\
\hline & $(0.0257)$ & $(0.0292)$ & $(0.0281)$ & $(0.0281)$ & $(0.0430)$ & $(0.0324)$ \\
\hline \multirow{2}{*}{$\ln p_{i, t}^{K}$} & $0.0432^{* * *}$ & $0.0442^{* * *}$ & $0.0424^{* * *}$ & $0.0463^{* * *}$ & $0.0319^{* *}$ & $0.0227^{* *}$ \\
\hline & $(0.0090)$ & $(0.0098)$ & $(0.0096)$ & $(0.0067)$ & $(0.0137)$ & $(0.0088)$ \\
\hline \multirow[t]{2}{*}{$\ln p_{i, t-1}^{K}$} & - & - & - & 0.0078 & - & - \\
\hline & - & - & - & $(0.0106)$ & - & - \\
\hline \multirow[t]{2}{*}{$\ln p_{i, t}^{I I}$} & $0.1817^{* *}$ & $0.1802^{* *}$ & $0.1716^{* *}$ & $0.1968^{* * *}$ & - & $0.2039^{* * *}$ \\
\hline & $(0.0751)$ & $(0.0699)$ & $(0.0767)$ & $(0.0677)$ & - & $(0.0550)$ \\
\hline \multirow{2}{*}{$\ln p_{i, t}^{E}$} & - & - & - & - & $-0.1315^{* * *}$ & - \\
\hline & - & - & - & - & $(0.0271)$ & - \\
\hline \multirow{2}{*}{$\ln p_{i, t}^{M}$} & - & - & - & - & $0.1372^{* *}$ & - \\
\hline & - & - & - & - & $(0.0573)$ & - \\
\hline \multirow{2}{*}{$\ln p_{i, t}^{S}$} & - & - & - & - & -0.0893 & - \\
\hline & - & - & - & - & $(0.0583)$ & - \\
\hline \multirow[t]{2}{*}{$\ln s_{t}$} & $-0.1253^{*}$ & - & - & - & - & - \\
\hline & $(0.0747)$ & - & - & - & - & - \\
\hline \multirow[t]{2}{*}{$\ln s_{t-1}$} & - & $-0.2628^{* * *}$ & - & $-0.2277^{* * *}$ & $-0.2741^{* * *}$ & $-0.1198^{* *}$ \\
\hline & - & $(0.0667)$ & - & $(0.0855)$ & $(0.0931)$ & $(0.0557)$ \\
\hline \multirow{2}{*}{$\ln s_{t}^{m a}$} & - & - & $-0.3252^{* *}$ & - & - & - \\
\hline & - & - & $(0.1293)$ & - & - & - \\
\hline \multirow[t]{2}{*}{$\ln Y_{t}$} & $0.1422^{* *}$ & $0.0873^{* * *}$ & 0.0458 & $0.1008^{* * *}$ & -0.0184 & $0.0941^{* * *}$ \\
\hline & $(0.0700)$ & $(0.0331)$ & $(0.0862)$ & $(0.0373)$ & $(0.0525)$ & $(0.0351)$ \\
\hline \multirow[t]{2}{*}{ CUSFTA $A_{t}$} & $-0.0177^{* *}$ & $-0.0125^{*}$ & -0.0107 & -0.0138 & $-0.0358^{* * *}$ & $-0.0302^{* * *}$ \\
\hline & $(0.0078)$ & $(0.0075)$ & $(0.0080)$ & $(0.0089)$ & $(0.0126)$ & $(0.0069)$ \\
\hline \multirow[t]{2}{*}{$N A F T A_{t}$} & $-0.0595^{* * *}$ & $-0.0557^{* * *}$ & $-0.0551^{* * *}$ & $-0.0615^{* * *}$ & $-0.0650^{* * *}$ & $-0.0609^{* * *}$ \\
\hline & $(0.0074)$ & $(0.0068)$ & $(0.0080)$ & $(0.0088)$ & $(0.0095)$ & $(0.0089)$ \\
\hline \multicolumn{7}{|c|}{ Measures of Fit - Estimation } \\
\hline$R$-squared & 0.9751 & 0.9757 & 0.9755 & 0.9743 & 0.9826 & 0.9773 \\
\hline Adjusted $R$-squared & 0.9468 & 0.9481 & 0.9514 & 0.9488 & 0.9447 & 0.9491 \\
\hline \multicolumn{7}{|c|}{ Measures of Fit - Dynamic In-sample Prediction } \\
\hline Mean absolute error ${ }^{a}$ & 0.0537 & 0.0538 & 0.0538 & 0.0515 & 0.0501 & 0.0544 \\
\hline Root mean squared error ${ }^{b}$ & 0.0710 & 0.0701 & 0.0707 & 0.0673 & 0.0655 & 0.0707 \\
\hline \multirow{3}{*}{$\begin{array}{c}\text { Of Interest } \\
\text { Speed of adjustment }\end{array}$} & & & & & & \\
\hline & $0.3736^{* * *}$ & $0.3814^{* * *}$ & $0.3618^{* * *}$ & $0.4308^{* * *}$ & $0.4715^{* * *}$ & $0.4514^{* * *}$ \\
\hline & $(0.0634)$ & $(0.0563)$ & $(0.0632)$ & $(0.0613)$ & $(0.0425)$ & $(0.0463)$ \\
\hline \multirow[t]{2}{*}{ Long-run elasticity $^{d}$} & -0.3354 & $-0.6891^{* * *}$ & $-0.8989^{*}$ & $-0.5285^{* *}$ & $-0.5812^{* * *}$ & $-0.2654^{*}$ \\
\hline & $(0.2242)$ & $(0.2056)$ & $(0.4856)$ & $(0.2313)$ & $(0.1822)$ & $(0.1290)$ \\
\hline
\end{tabular}

${ }^{a}$ The mean absolute error is the average over the sample of the absolute value of the differences between predicted and the true observation. It's a linear score, where all the individual differences are weighted equally. To compute the score, we sum the absolute differences for each cross-section separately, sum for all cross-sections, and finally take the mean value by dividing by the total number of observations.

${ }^{b}$ The root mean squared error is the average over the sample of the squared value of the differences between predicted and the true observation. It's a quadratic score, where large errors are weighted with a relatively higher weight. To compute the score, we sum the squared differences for each cross-section separately, sum for all cross-sections, take the mean value by dividing by the total number of observations, and finally take the root.

${ }^{c}$ The speed of adjustment is one minus the coefficient(s) on the lagged labour input. We compute a linear Wald test to test the parameter combination, and standard errors and p-value are computed using delta method.

${ }^{d}$ The long-run elasticity is the coefficient on the real exchange rate divided by the speed of adjustment. We compute a nonlinear Wald test to test the parameter combination, and standard errors and p-value are computed using delta method. 
The influence of world GDP $\left(Y_{t}\right)$ is positive and sizeable, with a short-term elasticity of 0.1422 ; this estimate therefore suggests that a given percentage increase in world GDP has a bigger influence on the labour input of Canadian manufacturing industries than an equal-valued depreciation of the exchange rate. This specific result is not robust, however: in columns (2) and (3), the impact of changes in the exchange rate is stronger than that of changes to world GDP. Finally, the coefficients on CUSFT $A_{t}$ and especially $N A F T A_{t}$ are also statistically and economically significant. Notably, according to the benchmark results in column (1), the enactment of $N A F T A_{t}$ has lead to a decrease of almost $6 \%$ in hours worked at Canadian manufacturing employers initially, with a long-term impact of up to $-16 \%$.

Columns (4) to (6) provide a sensitivity analysis of these results to extensions from the benchmark specification. These extensions retain the lagged exchange rate $\left(s_{t-1}\right)$, because column (2) reports that this specification outperforms both columns (1) and (3). Column (4) adds a lag of the relative user cost of capital, in order to allow for a more complex pattern of substitution between capital and labour. Results are mostly unchanged, however, and the added regressor is not statistically significant. Column (5) analyzes the case where the relative price of intermediate inputs $\left(p_{i, t}^{I I}\right)$ is disaggregated into subcomponents for the price of energy, the price of materials and the price of services. While such addition of information does improve slightly some measures of fit, it does so at a cost of a loss in degrees of freedom and a decrease in the adjusted $R^{2}$ statistic, relative to column (2). ${ }^{13}$ The added information also affects some of the estimated coefficients: while the immediate impact of the exchange rate is virtually unchanged from column (2), the estimated speed of adjustment increases while the long-run elasticity decreases. In addition, this specification allows the identification of a separate impact from the price of energy inputs $\left(p_{i, t}^{E}\right)$ : this impact is negative, which suggests that energy use and labour inputs are complementary. Finally, the coefficient on material is positive, while the one on services in not significant. Notice as well that under this specification, the impact of world GDP is not significant. Column (6) explores the consequence of adding the second lag of the labour input to the estimated equation: this has a mixed effect on the fit of the equation, with two measures

\footnotetext{
${ }^{13}$ The disaggregation of the relative price of intermediate inputs $\left(p_{i, t}^{I I}\right)$ into its subcomponents requires the addition of forty estimated parameters in the context where all the industries are considered in our panel within DOLS.
} 
reporting an improvement of fit relative to column (2) but two others recording a worsening. Interestingly, the resulting coefficients, 0.82 on the first lag and -0.27 on the second combine into an estimated speed of adjustment that is slightly higher but not out of line relative to the one in column (2) (0.45 compared to 0.38). The long-run impact is estimated to be significantly lower than under the specification in column (2), however.

Overall, therefore, Table 5 suggests that exchange rate movements have statistically and economically significant on Canadian manufacturing firms. Our preferred specification in column (2) shows that a 10\% (real) appreciation of the Canadian dollar will reduce the labour input of these firms by $7 \%$ in the long run, at a speed that closes about $40 \%$ of the gap between realized and targeted labour every year. Table 5 also provides a sensitivity analysis that suggests a likely range of values for the long-run impact of exchange rate changes would be between $3 \%$ and $9 \%$, with a narrower range, between $37 \%$ and $45 \%$, for the speed of adjustment. The following subsections verify the robustness of these results to alternative measures of the labour input and to difference in foreign trade exposure across industries.

\subsection{Alternative Measures of the Labour Input}

Table 6 reports the estimates arrived at when the labour input is measured by $H_{i, t}$, a simple sum of all hours worked in industry $i$. Recall that by contrast to $L_{i, t}$, this measure makes no attempt to correct hours worked for the quality of labour (experience, education, etc.). Significant differences between the two sets of results would suggest that real exchange rate fluctuations can have significant compositional effects on the labour input of Canadian manufacturing firms, in addition to the aggregate effects already established.

However, Table 6 finds little evidence supporting the presence of such compositional effects. Both the short term and long term impact from exchange rate movements closely resemble those depicted in Table 5; for our preferred specification using the lagged value of the exchange rate (column (2)), a 10\% depreciation again leads to a decrease of close to $7 \%$ in labour, with just under $40 \%$ of the gap between realized and targeted labour closed every year. Further, world GDP and the enactment of trade agreements continue to exert sizeable influences on hours worked in manufacturing, similar in size to those described previously in Table 5. 
Table 6: Estimation Results - Hours $H_{i, t}$ - All Industries

\begin{tabular}{|c|c|c|c|c|c|c|}
\hline \multirow[t]{2}{*}{ Regressors } & \multicolumn{6}{|c|}{ Specifications } \\
\hline & (1) & $(2)$ & $(3)$ & (4) & $(5)$ & (6) \\
\hline \multirow[t]{2}{*}{$\ln H_{i, t-1}$} & $0.6121^{* * *}$ & $0.6118^{* * *}$ & $0.6260^{* * *}$ & $0.5639^{* * *}$ & $0.5176^{* * *}$ & $0.7765^{* * *}$ \\
\hline & $(0.0600)$ & $(0.0512)$ & $(0.0592)$ & $(0.0589)$ & $(0.0584)$ & $(0.0572)$ \\
\hline \multirow{2}{*}{$\ln H_{i, t-2}$} & - & - & - & - & - & $-0.2576^{* * *}$ \\
\hline & - & - & - & - & - & $(0.0326)$ \\
\hline \multirow[t]{2}{*}{$\ln w_{i, t}$} & $-0.1295^{* * *}$ & $-0.0986^{* * *}$ & $-0.1059^{* * *}$ & $-0.1100^{* * *}$ & -0.0627 & $-0.0921^{* * *}$ \\
\hline & $(0.0287)$ & $(0.0353)$ & $(0.0333)$ & $(0.0339)$ & $(0.0505)$ & $(0.0308)$ \\
\hline \multirow{2}{*}{$\ln p_{i, t}^{K}$} & $0.0474^{* * *}$ & $0.0475^{* * *}$ & $0.0471^{* * *}$ & $0.0473^{* * *}$ & $0.0361^{* * *}$ & $0.0271^{* * *}$ \\
\hline & $(0.0090)$ & $(0.0093)$ & $(0.0097)$ & $(0.0075)$ & $(0.0137)$ & $(0.0089)$ \\
\hline \multirow{2}{*}{$\ln p_{i, t-1}^{K}$} & - & - & - & 0.0108 & - & - \\
\hline & - & - & - & $(0.0098)$ & - & - \\
\hline \multirow{2}{*}{$\ln p_{i, t}^{I I}$} & $0.1809^{* *}$ & $0.1767^{* *}$ & $0.1692^{* *}$ & $0.1963^{* * *}$ & - & $0.2112^{* * *}$ \\
\hline & $(0.0769)$ & $(0.0691)$ & $(0.0769)$ & $(0.0693)$ & - & $(0.0547)$ \\
\hline \multirow[t]{2}{*}{$\ln p_{i, t}^{E}$} & - & - & - & - & $-0.1392^{* * *}$ & - \\
\hline & - & - & - & - & $(0.0282)$ & - \\
\hline \multirow{2}{*}{$\ln p_{i, t}^{M}$} & - & - & - & - & $0.1209^{* *}$ & - \\
\hline & - & - & - & - & $(0.0515)$ & - \\
\hline \multirow[t]{2}{*}{$\ln p_{i, t}^{S}$} & - & - & - & - & -0.0744 & - \\
\hline & - & - & - & - & $(0.0581)$ & - \\
\hline \multirow[t]{2}{*}{$\ln s_{t}$} & -0.1136 & - & - & - & - & - \\
\hline & $(0.0800)$ & - & - & - & - & - \\
\hline \multirow[t]{2}{*}{$\ln s_{t-1}$} & - & $-0.2540^{* * *}$ & - & $-0.2261^{* *}$ & $-0.2974^{* * *}$ & $-0.1168^{* *}$ \\
\hline & - & $(0.0655)$ & - & $(0.0872)$ & $(0.0933)$ & $(0.0492)$ \\
\hline \multirow[t]{2}{*}{$\ln s_{t}^{m a}$} & - & - & $-0.2464^{*}$ & - & - & - \\
\hline & - & - & $(0.1461)$ & - & - & - \\
\hline \multirow[t]{2}{*}{$\ln Y_{t}$} & $0.1600^{* *}$ & $0.0911^{* * *}$ & 0.1017 & $0.0921^{* *}$ & -0.0369 & $0.1025^{* * *}$ \\
\hline & $(0.0715)$ & $(0.0344)$ & $(0.0895)$ & $(0.0356)$ & $(0.0536)$ & $(0.0374)$ \\
\hline \multirow[t]{2}{*}{$C U S F T A_{t}$} & $-0.0185^{* *}$ & $-0.0141^{*}$ & -0.0136 & $-0.0162^{*}$ & $-0.0402^{* * *}$ & $-0.0278^{* * *}$ \\
\hline & $(0.0082)$ & $(0.0084)$ & $(0.0093)$ & $(0.0094)$ & $(0.0146)$ & $(0.0070)$ \\
\hline \multirow[t]{2}{*}{$N A F T A_{t}$} & $-0.0630^{* * *}$ & $-0.0577^{* * *}$ & $-0.0591^{* * *}$ & $-0.0623^{* * *}$ & $-0.0695^{* * *}$ & $-0.0630^{* * *}$ \\
\hline & $(0.0078)$ & $(0.0071)$ & $(0.0080)$ & $(0.0098)$ & $(0.0128)$ & $(0.0097)$ \\
\hline \multicolumn{7}{|c|}{ Measures of Fit - Estimation } \\
\hline$R$-squared & 0.9749 & 0.9751 & 0.9749 & 0.9737 & 0.9823 & 0.9770 \\
\hline Adjusted R-squared & 0.9502 & 0.9468 & 0.9503 & 0.9477 & 0.9440 & 0.9483 \\
\hline \multicolumn{7}{|c|}{ Measures of Fit - Dynamic In-sample Prediction } \\
\hline Mean absolute error & 0.0538 & 0.0536 & 0.0538 & 0.0512 & 0.0497 & 0.0532 \\
\hline Root mean squared error & 0.0714 & 0.0705 & 0.0710 & 0.0674 & 0.0657 & 0.0706 \\
\hline \multicolumn{7}{|l|}{ Of Interest } \\
\hline \multirow[t]{2}{*}{ Speed of adjustment } & $0.3879^{* * *}$ & $0.3882^{* * *}$ & $0.3740^{* * *}$ & $0.4361^{* * *}$ & $0.4824^{* * *}$ & $0.4811^{* * *}$ \\
\hline & $(0.0600)$ & $(0.0512)$ & $(0.0592)$ & $(0.0589)$ & $(0.0749)$ & $(0.0454)$ \\
\hline \multirow[t]{2}{*}{ Long-run elasticity } & -0.2929 & $-0.6544^{* * *}$ & -0.6586 & $-0.5183^{* *}$ & $-0.6166^{* *}$ & $-0.2427^{* *}$ \\
\hline & $(0.2189)$ & $(0.2022)$ & $(0.4634)$ & $(0.2309)$ & $(0.2715)$ & $(0.1089)$ \\
\hline
\end{tabular}

By contrast, interesting differences do appear in Table 7, which depicts results using employment $E_{i, t}$, an indicator concentrating on the extensive margin of the labour market. Most notably, the speed of adjustment towards targeted employed appears to be faster: between $60 \%$ (column (2)) and 70\% (column (5)) of the gap between targeted and actual employment is closed every period, compared to estimated adjustment speed around $40 \%$ in results presented above. The long-run impact of changes in the exchange rate continue to be sizeable, with a $10 \%$ real depreciation implying a likely decline in manufacturing em- 
ployment in the $4 \%$ (column (6)) to $10 \%$ (column (3)) range. The higher estimated speed of adjustment for employment suggests that following real exchange rate appreciations, Canadian manufacturing employers reduce employment relatively quickly but that total hours decline gradually, implying that employees retaining their jobs experience a pick-up in their hours worked. Interestingly, the relative influence of trade agreements also changes: the US-Canada Free Trade Agreement of 1989 (the variable $C U S F T A_{t}$ ) now has a significant and negative impact on employment, while the influence of the North American trade pact of 1994 does not. Further, the impact of world GDP is now noticeably higher than it was for the other two measures of labour input.

\subsection{Trade Exposure}

The analysis so far has assumed that exchange rate fluctuations have a common impact on the labour input decisions of all industries. However, that impact should in principle depend on a specific industry's openness to trade, both to exports (so that a depreciation facilitates selling in foreign markets) and to imports (as the same depreciation reduces the competitiveness of foreign producers in domestic markets). To assess the importance of this issue, we report estimation results that control for the net trade exposure (NTE) of the industries in our dataset.

In that context, Table 8 reports estimation results for the high-NTE industries, using the quality-adjusted labour input $L_{i, t} \cdot{ }^{14}$ Qualitatively, results are similar to their all-industries counterpart in Table 5: the lagged labour input measure is highly significant, and so are coefficients on the price of labour, the price of capital, exchange rates, world GDP and trade agreements, with unchanged signs from those in Table $5 .{ }^{15}$ However, important quantitative differences are present: while the speed of adjustment is virtually unchanged from before (at around 0.4), the impact of exchange rate fluctuations, of world GDP, and of the trade agreements have all increased significantly: a $10 \%$ depreciation now ultimately decreases $L_{i, t}$ by $10 \%$ (column (2)); NAFT $A_{t}$ is found to have decreased $L_{i, t}$ initially by close to $7 \%$; and the impact of movements in world GDP has nearly doubled. Table 8 thus provides strong

\footnotetext{
${ }^{14}$ Recall that high-NTE industries are those above the Canadian average for manufacturing: 14 out of our 20 industries are classified as high-NTE. See Appendix B for details on classification and Section 3 about how net trade exposure is measured.

${ }^{15}$ In addition, using the lagged value of the exchange rate continues to deliver good measures of fit, as does the specification using two lags of the labour input.
} 
evidence that, as conjectured, trade openness is a key factor in the link between exchange rate fluctuations and the labour input decisions of Canadian manufacturing employers.

Table 7: Estimation Results - Employment $E_{i, t}$ - All Industries

\begin{tabular}{|c|c|c|c|c|c|c|}
\hline \multirow[t]{2}{*}{ Regressors } & \multicolumn{6}{|c|}{ Specifications } \\
\hline & (1) & (2) & (3) & (4) & (5) & (6) \\
\hline $\ln E_{i, t-1}$ & $\begin{array}{l}0.4313^{* * *} \\
(0.0491)\end{array}$ & $\begin{array}{l}0.4036^{* * *} \\
(0.0502)\end{array}$ & $\begin{array}{l}0.4316^{* * *} \\
(0.0492)\end{array}$ & $\begin{array}{l}0.4108^{* * *} \\
(0.0579)\end{array}$ & $\begin{array}{l}0.2944^{* * *} \\
(0.0446)\end{array}$ & $\begin{array}{l}0.3383^{* * *} \\
(0.0399)\end{array}$ \\
\hline $\ln E_{i, t-2}$ & $\begin{array}{l}- \\
-\end{array}$ & $\begin{array}{l}- \\
-\end{array}$ & $\begin{array}{l}- \\
-\end{array}$ & - & $\begin{array}{l}- \\
-\end{array}$ & $\begin{array}{l}-0.0440 \\
(0.0519)\end{array}$ \\
\hline $\ln w_{i, t}$ & $\begin{array}{c}0.0008 \\
(0.0596)\end{array}$ & $\begin{array}{c}0.0143 \\
(0.0696)\end{array}$ & $\begin{array}{c}0.0153 \\
(0.0683)\end{array}$ & $\begin{array}{l}-0.0030 \\
(0.0575)\end{array}$ & $\begin{array}{l}0.1218^{* * *} \\
(0.0457)\end{array}$ & $\begin{array}{c}0.0558 \\
(0.0820)\end{array}$ \\
\hline $\ln p_{i, t}^{K}$ & $\begin{array}{c}0.0566^{* *} \\
(0.0248)\end{array}$ & $\begin{array}{c}0.0527^{* *} \\
(0.0262)\end{array}$ & $\begin{array}{c}0.0553^{* *} \\
(0.0254)\end{array}$ & $\begin{array}{l}0.0467^{* * *} \\
(0.0170)\end{array}$ & $\begin{array}{c}0.0037 \\
(0.0240)\end{array}$ & $\begin{array}{c}0.0305 \\
(0.0240)\end{array}$ \\
\hline $\ln p_{i, t-1}^{K}$ & - & $\begin{array}{l}- \\
-\end{array}$ & $\begin{array}{l}- \\
-\end{array}$ & $\begin{array}{c}0.0083 \\
(0.0171)\end{array}$ & $\begin{array}{l}- \\
-\end{array}$ & - \\
\hline $\ln p_{i, t}^{I I}$ & $\begin{array}{c}0.0403 \\
(0.0515)\end{array}$ & $\begin{array}{l}-0.0173 \\
(0.0413)\end{array}$ & $\begin{array}{c}0.0354 \\
(0.0437)\end{array}$ & $\begin{array}{l}-0.0508 \\
(0.0402)\end{array}$ & $\begin{array}{l}- \\
-\end{array}$ & $\begin{array}{l}-0.0121 \\
(0.0456)\end{array}$ \\
\hline $\ln p_{i, t}^{E}$ & $\begin{array}{l}- \\
-\end{array}$ & - & $\begin{array}{l}- \\
-\end{array}$ & - & $\begin{array}{l}-0.0886 \\
(0.0572)\end{array}$ & $\begin{array}{l}- \\
-\end{array}$ \\
\hline $\ln p_{i, t}^{M}$ & $\begin{array}{l}- \\
-\end{array}$ & $\begin{array}{l}- \\
-\end{array}$ & - & - & $\begin{array}{l}-0.1417^{* *} \\
(0.0596)\end{array}$ & $\begin{array}{l}- \\
-\end{array}$ \\
\hline $\ln p_{i, t}^{S}$ & $\begin{array}{l}- \\
-\end{array}$ & $\begin{array}{l}- \\
-\end{array}$ & $\begin{array}{l}- \\
-\end{array}$ & - & $\begin{array}{l}-0.2823^{* * *} \\
(0.0711)\end{array}$ & $\begin{array}{l}- \\
-\end{array}$ \\
\hline $\ln s_{t}$ & $\begin{array}{l}-0.0864 \\
(0.1272)\end{array}$ & $\begin{array}{l}- \\
-\end{array}$ & - & $\begin{array}{l}- \\
-\end{array}$ & - & - \\
\hline $\ln s_{t-1}$ & $\begin{array}{l}- \\
-\end{array}$ & $\begin{array}{l}-0.3493^{* *} \\
(0.1640)\end{array}$ & $\begin{array}{l}- \\
-\end{array}$ & $\begin{array}{l}-0.3392^{* *} \\
(0.1472)\end{array}$ & $\begin{array}{l}-0.4904^{* * *} \\
(0.0927)\end{array}$ & $\begin{array}{l}-0.2944^{* *} \\
(0.1320)\end{array}$ \\
\hline $\ln s_{t, 2 m a}$ & $\begin{array}{l}- \\
-\end{array}$ & - & $\begin{array}{l}-0.5844^{* *} \\
(0.2384)\end{array}$ & $\begin{array}{l}- \\
-\end{array}$ & $\begin{array}{l}- \\
-\end{array}$ & - \\
\hline $\ln Y_{t}$ & $\begin{array}{c}0.1919 \\
(0.1238)\end{array}$ & $\begin{array}{c}0.1383 \\
(0.1024)\end{array}$ & $\begin{array}{l}-0.0727 \\
(0.1653)\end{array}$ & $\begin{array}{c}0.1263 \\
(0.1036)\end{array}$ & $\begin{array}{l}0.3016^{* * *} \\
(0.0728)\end{array}$ & $\begin{array}{l}0.1784^{* * *} \\
(0.0661)\end{array}$ \\
\hline CUSFTAt & $\begin{array}{l}-0.0698^{* * *} \\
(0.0260)\end{array}$ & $\begin{array}{l}-0.0537^{* *} \\
(0.0252)\end{array}$ & $\begin{array}{l}-0.0513^{* *} \\
(0.0234)\end{array}$ & $\begin{array}{l}-0.0523^{* *} \\
(0.0242)\end{array}$ & $\begin{array}{l}-0.0546^{* *} \\
(0.0241)\end{array}$ & $\begin{array}{l}-0.0659^{* * *} \\
(0.0234)\end{array}$ \\
\hline$N A F T A_{t}$ & $\begin{array}{l}-0.0100 \\
(0.0199)\end{array}$ & $\begin{array}{l}-0.0163 \\
(0.0192)\end{array}$ & $\begin{array}{l}-0.0010 \\
(0.0202)\end{array}$ & $\begin{array}{l}-0.0117 \\
(0.0196)\end{array}$ & $\begin{array}{l}-0.0794^{* * *} \\
(0.0179)\end{array}$ & $\begin{array}{l}-0.0276^{* *} \\
(0.0190)\end{array}$ \\
\hline Measures of Fit - Estin & ation & & & & & \\
\hline $\begin{array}{l}R \text {-squared } \\
\text { Adjusted } R \text {-squared }\end{array}$ & $\begin{array}{l}0.9751 \\
0.8846\end{array}$ & $\begin{array}{l}0.9388 \\
0.8691\end{array}$ & $\begin{array}{l}0.9426 \\
0.8862\end{array}$ & $\begin{array}{l}0.9390 \\
0.8787\end{array}$ & $\begin{array}{l}0.9634 \\
0.8839\end{array}$ & $\begin{array}{l}0.9431 \\
0.8722\end{array}$ \\
\hline Measures of Fit - Dyno & nic In-sampl & Prediction & & & & \\
\hline Mean absolute error & 0.0735 & 0.0703 & 0.0721 & 0.0700 & 0.0711 & 0.0711 \\
\hline Root mean squared error & 0.0943 & 0.0904 & 0.0940 & 0.0895 & 0.0928 & 0.0924 \\
\hline $\begin{array}{c}\text { Of Interest } \\
\text { Speed of adjustment }\end{array}$ & $\begin{array}{l}0.5687^{* * *} \\
(0.0491)\end{array}$ & $\begin{array}{l}0.5964^{* * *} \\
(0.0502)\end{array}$ & $\begin{array}{l}0.5684^{* * *} \\
(0.0492)\end{array}$ & $\begin{array}{l}0.5892^{* * *} \\
(0.0579)\end{array}$ & $\begin{array}{l}0.7055^{* * *} \\
(0.0818)\end{array}$ & $\begin{array}{l}0.7057^{* * *} \\
(0.0543)\end{array}$ \\
\hline Long-run elasticity & $\begin{array}{l}-0.1519 \\
(0.2300)\end{array}$ & $\begin{array}{l}-0.5856^{*} \\
(0.2921)\end{array}$ & $\begin{array}{l}-1.0280^{* *} \\
(0.4757)\end{array}$ & $\begin{array}{l}-0.5757^{* *} \\
(0.2729)\end{array}$ & $\begin{array}{l}-0.6949^{* *} \\
(0.2753)\end{array}$ & $\begin{array}{l}-0.4171^{* *} \\
(0.1974)\end{array}$ \\
\hline
\end{tabular}


Table 8: Estimation Results - Labour Input $L_{i, t}$ - High NTE Industries

\begin{tabular}{|c|c|c|c|c|c|c|}
\hline \multirow[t]{2}{*}{ Regressors } & \multicolumn{6}{|c|}{ Specifications } \\
\hline & (1) & (2) & $(3)$ & $(4)$ & $(5)$ & (6) \\
\hline $\ln L_{i, t-1}$ & $\begin{array}{l}0.6066^{* * *} \\
(0.0789)\end{array}$ & $\begin{array}{l}0.5963^{* * *} \\
(0.0747)\end{array}$ & $\begin{array}{l}0.6205^{* * *} \\
(0.0810)\end{array}$ & $\begin{array}{l}0.6057^{* * *} \\
(0.0634)\end{array}$ & $\begin{array}{l}0.5164^{* * *} \\
(0.0732)\end{array}$ & $\begin{array}{l}0.7469^{* * *} \\
(0.0722)\end{array}$ \\
\hline $\ln L_{i, t-2}$ & - & $\begin{array}{l}- \\
-\end{array}$ & $\begin{array}{l}- \\
-\end{array}$ & $\begin{array}{l}- \\
-\end{array}$ & $\begin{array}{l}- \\
-\end{array}$ & $\begin{array}{l}-0.2665^{* * *} \\
(0.0406)\end{array}$ \\
\hline $\ln w_{i, t}$ & $\begin{array}{l}-0.0888^{* *} \\
(0.0413)\end{array}$ & $\begin{array}{l}-0.0413 \\
(0.0429)\end{array}$ & $\begin{array}{l}-0.0522 \\
(0.0458)\end{array}$ & $\begin{array}{l}-0.0433 \\
(0.0418)\end{array}$ & $\begin{array}{l}-0.0803^{*} \\
(0.0472)\end{array}$ & $\begin{array}{c}0.0283 \\
(0.0358)\end{array}$ \\
\hline $\ln p_{i, t}^{K}$ & $\begin{array}{c}0.0310^{* *} \\
(0.0125)\end{array}$ & $\begin{array}{c}0.0328^{* *} \\
(0.0152)\end{array}$ & $\begin{array}{c}0.0277^{* *} \\
(0.0136)\end{array}$ & $\begin{array}{l}0.0637^{* * *} \\
(0.0112)\end{array}$ & $\begin{array}{c}0.0070 \\
(0.0186)\end{array}$ & $\begin{array}{c}0.0142 \\
(0.0137)\end{array}$ \\
\hline $\ln p_{i, t-1}^{K}$ & - & - & - & $\begin{array}{l}-0.0360^{* * *} \\
(0.0098)\end{array}$ & - & - \\
\hline $\ln p_{i, t}^{I I}$ & $\begin{array}{c}0.0610 \\
(0.0774)\end{array}$ & $\begin{array}{c}0.0521 \\
(0.0888)\end{array}$ & $\begin{array}{c}0.0278 \\
(0.0826)\end{array}$ & $\begin{array}{c}0.0154 \\
(0.1014)\end{array}$ & $\begin{array}{l}- \\
-\end{array}$ & $\begin{array}{c}0.0319 \\
(0.0790)\end{array}$ \\
\hline $\ln p_{i, t}^{E}$ & - & - & - & - & $\begin{array}{l}-0.1015^{* * *} \\
(0.0375)\end{array}$ & $\begin{array}{l}- \\
-\end{array}$ \\
\hline $\ln p_{i, t}^{M}$ & $\begin{array}{l}- \\
-\end{array}$ & $\begin{array}{l}- \\
-\end{array}$ & $\begin{array}{l}- \\
-\end{array}$ & $\begin{array}{l}- \\
-\end{array}$ & $\begin{array}{l}-0.0541 \\
(0.0988)\end{array}$ & $\begin{array}{l}- \\
-\end{array}$ \\
\hline $\ln p_{i, t}^{S}$ & - & - & - & - & $\begin{array}{l}-0.0112 \\
(0.0665)\end{array}$ & $\begin{array}{l}- \\
-\end{array}$ \\
\hline $\ln s_{t}$ & $\begin{array}{l}-0.2291^{* * *} \\
(0.0843)\end{array}$ & $\begin{array}{l}- \\
-\end{array}$ & - & $\begin{array}{l}- \\
-\end{array}$ & $\begin{array}{l}- \\
-\end{array}$ & $\begin{array}{l}- \\
-\end{array}$ \\
\hline $\ln s_{t-1}$ & $\begin{array}{l}- \\
-\end{array}$ & $\begin{array}{l}-0.4032^{* * *} \\
(0.1006)\end{array}$ & - & $\begin{array}{l}-0.3670^{* * *} \\
(0.1123)\end{array}$ & $\begin{array}{l}-0.4825^{* * *} \\
(0.1043)\end{array}$ & $\begin{array}{l}-0.2606^{* *} \\
(0.1018)\end{array}$ \\
\hline $\ln s_{t}^{m a}$ & - & $\begin{array}{l}- \\
-\end{array}$ & $\begin{array}{l}-0.5437^{* * *} \\
(0.1322)\end{array}$ & $\begin{array}{l}- \\
-\end{array}$ & $\begin{array}{l}- \\
-\end{array}$ & $\begin{array}{l}- \\
-\end{array}$ \\
\hline $\ln Y_{t}$ & $\begin{array}{c}0.2257^{* *} \\
(0.0878)\end{array}$ & $\begin{array}{l}0.1597^{* * *} \\
(0.0575)\end{array}$ & $\begin{array}{c}0.0716 \\
(0.1203)\end{array}$ & $\begin{array}{l}0.1823^{* * *} \\
(0.0608)\end{array}$ & $\begin{array}{l}0.1985^{* * *} \\
(0.0523)\end{array}$ & $\begin{array}{l}0.1937^{* * *} \\
(0.0577)\end{array}$ \\
\hline$C U S F T A_{t}$ & $\begin{array}{l}-0.0259^{* *} \\
(0.0103)\end{array}$ & $\begin{array}{l}-0.0159 \\
(0.0105)\end{array}$ & $\begin{array}{l}-0.0124 \\
(0.0099)\end{array}$ & $\begin{array}{l}-0.0170^{*} \\
(0.0101)\end{array}$ & $\begin{array}{l}-0.0365^{* * *} \\
(0.0123)\end{array}$ & $\begin{array}{l}-0.0325^{* * *} \\
(0.0105)\end{array}$ \\
\hline$N A F T A_{t}$ & $\begin{array}{l}-0.0691^{* * *} \\
(0.0160)\end{array}$ & $\begin{array}{l}-0.0645^{* * *} \\
(0.0173)\end{array}$ & $\begin{array}{l}-0.0620^{* * *} \\
(0.0183)\end{array}$ & $\begin{array}{l}-0.0674^{* * *} \\
(0.0177)\end{array}$ & $\begin{array}{l}-0.0822^{* * *} \\
(0.0121)\end{array}$ & $\begin{array}{l}-0.0693^{* * *} \\
(0.0153)\end{array}$ \\
\hline Measures of Fit - Estin & ation & & & & & \\
\hline$R$-squared & 0.9814 & 0.9822 & 0.9820 & 0.9818 & 0.9889 & 0.9836 \\
\hline Adjusted $R$-squared & 0.9628 & 0.9644 & 0.9639 & 0.9604 & 0.9639 & 0.9626 \\
\hline $\begin{array}{l}\text { Measures of Fit - Dync } \\
\text { Mean absolute error }\end{array}$ & $\begin{array}{l}\text { nic In-sampl } \\
0.0537\end{array}$ & $\begin{array}{l}\text { Prediction } \\
0.0532\end{array}$ & 0.0542 & 0.0528 & 0.0527 & 0.0528 \\
\hline Root mean squared error & 0.0683 & 0.0683 & 0.0695 & 0.0670 & 0.0672 & 0.0672 \\
\hline $\begin{array}{c}\text { Of Interest } \\
\text { Speed of adjustment }\end{array}$ & $\begin{array}{l}0.3934^{* * *} \\
(0.0789)\end{array}$ & $\begin{array}{l}0.4037^{* * *} \\
(0.0747)\end{array}$ & $\begin{array}{l}0.3795^{* * *} \\
(0.0810)\end{array}$ & $\begin{array}{l}0.3943^{* * *} \\
(0.0634)\end{array}$ & $\begin{array}{l}0.4836^{* * *} \\
(0.0732)\end{array}$ & $\begin{array}{l}0.5196^{* * *} \\
(0.0664)\end{array}$ \\
\hline Long-run elasticity & $\begin{array}{l}-0.5823^{* *} \\
(0.2439)\end{array}$ & $\begin{array}{l}-0.9987^{* * *} \\
(0.3059)\end{array}$ & $\begin{array}{l}-1.4327^{* *} \\
(0.5858)\end{array}$ & $\begin{array}{l}-0.9308^{* *} \\
(0.3543)\end{array}$ & $\begin{array}{l}-0.9978^{* * *} \\
(0.2804)\end{array}$ & $\begin{array}{l}-0.5016^{* *} \\
(0.1901)\end{array}$ \\
\hline
\end{tabular}

Using alternative measures for the labour input confirms these findings. Table 9 (for hours $H_{i, t}$ ) and Table 10 (for employment $E_{i, t}$ ) report that high-NTE industries continue to produce estimates for the impact of exchange rate fluctuations that are stronger than their all-industries counterparts. In addition, the magnitudes of the coefficients on world GDP and the trade agreements continue to be higher. Importantly, the contrast between the behaviour of hours and employment discussed above, with employment reacting faster than hours and thus suggesting that hours per employee react countercyclically, is still present. 
Overall therefore, the impact of exchange rate fluctuations on the labour decisions of Canadian manufacturing employers is noticeably stronger in industries with higher-than-average openness to trade.

Table 9: Estimation Results - Hours $H_{i, t}$ - High NTE Industries

\begin{tabular}{|c|c|c|c|c|c|c|}
\hline \multirow[t]{2}{*}{ Regressors } & \multicolumn{6}{|c|}{ Specifications } \\
\hline & (1) & (2) & $(3)$ & $(4)$ & (5) & (6) \\
\hline \multirow[t]{2}{*}{$\ln H_{i, t-1}$} & $0.6061^{* * *}$ & $0.5981^{* * *}$ & $0.6201^{* * *}$ & $0.5915^{* * *}$ & $0.5010^{* * *}$ & $0.7206^{* * *}$ \\
\hline & $(0.0714)$ & $(0.0654)$ & $(0.0723)$ & $(0.0624)$ & $(0.0703)$ & $(0.0611)$ \\
\hline \multirow[t]{2}{*}{$\ln H_{i, t-2}$} & - & - & - & - & - & $-0.2685^{* * *}$ \\
\hline & - & - & - & - & - & $(0.0367)$ \\
\hline \multirow[t]{2}{*}{$\ln w_{i, t}$} & $-0.0706^{*}$ & -0.0260 & -0.0298 & -0.0328 & -0.0657 & 0.0354 \\
\hline & $(0.0393)$ & $(0.0414)$ & $(0.0424)$ & $(0.0419)$ & $(0.0475)$ & $(0.0350)$ \\
\hline \multirow{2}{*}{$\ln p_{i, t}^{K}$} & $0.0394^{* * *}$ & $0.0422^{* * *}$ & $0.0372^{* * *}$ & $0.0634^{* * *}$ & 0.0160 & $0.0266^{* *}$ \\
\hline & $(0.0122)$ & $(0.0146)$ & $(0.0132)$ & $(0.0124)$ & $(0.0196)$ & $(0.0134)$ \\
\hline \multirow{2}{*}{$\ln p_{i, t-1}^{K}$} & - & - & - & $-0.0261^{* * *}$ & - & - \\
\hline & - & - & - & $(0.0082)$ & - & - \\
\hline \multirow{2}{*}{$\ln p_{i, t}^{I I}$} & 0.1043 & 0.1045 & 0.0661 & 0.0641 & - & 0.1103 \\
\hline & $(0.0673)$ & $(0.0792)$ & $(0.0738)$ & $(0.0960)$ & - & $(0.0806)$ \\
\hline \multirow[t]{2}{*}{$\ln p_{i, t}^{E}$} & - & - & - & - & $-0.1029^{* * *}$ & - \\
\hline & - & - & - & - & $(0.0357)$ & - \\
\hline \multirow[t]{2}{*}{$\ln p_{i, t}^{M}$} & - & - & - & - & -0.0488 & - \\
\hline & - & - & - & - & $(0.0898)$ & - \\
\hline \multirow[t]{2}{*}{$\ln p_{i, t}^{S}$} & - & - & - & - & 0.0090 & - \\
\hline & - & - & - & - & $(0.0687)$ & - \\
\hline \multirow[t]{2}{*}{$\ln s_{t}$} & $-0.2264^{* * *}$ & - & - & - & - & - \\
\hline & $(0.0830)$ & - & - & - & - & - \\
\hline \multirow[t]{2}{*}{$\ln s_{t-1}$} & - & $-0.3759^{* * *}$ & - & $-0.3406^{* * *}$ & $-0.5185^{* * *}$ & $-0.2452^{* *}$ \\
\hline & - & $(0.0963)$ & - & $(0.1147)$ & $(0.1041)$ & $(0.0955)$ \\
\hline \multirow[t]{2}{*}{$\ln s_{t}^{m a}$} & - & - & $-0.4718^{* * *}$ & - & - & - \\
\hline & - & - & $(0.1371)$ & - & - & - \\
\hline \multirow[t]{2}{*}{$\ln Y_{t}$} & $0.1994^{* *}$ & $0.1354^{* *}$ & 0.0853 & $0.1586^{* *}$ & $0.1770^{* * *}$ & $0.1700^{* * *}$ \\
\hline & $(0.0855)$ & $(0.0538)$ & $(0.1151)$ & $(0.0629)$ & $(0.0576)$ & $(0.0567)$ \\
\hline \multirow{2}{*}{$C U S F T A_{t}$} & $-0.0258^{* *}$ & -0.0175 & -0.0145 & $-0.0201^{*}$ & $-0.0381^{* * *}$ & $-0.0299^{* * *}$ \\
\hline & $(0.0105)$ & $(0.0111)$ & $(0.0106)$ & $(0.0108)$ & $(0.0141)$ & $(0.0106)$ \\
\hline \multirow[t]{2}{*}{$N A F T A_{t}$} & $-0.0683^{* * *}$ & $-0.0632^{* * *}$ & $-0.0621^{* * *}$ & $-0.0664^{* * *}$ & $-0.0912^{* * *}$ & $-0.0704^{* * *}$ \\
\hline & $(0.0149)$ & $(0.0158)$ & $(0.0162)$ & $(0.0172)$ & $(0.0148)$ & $(0.0146)$ \\
\hline \multicolumn{7}{|c|}{ Measures of Fit - Estimation } \\
\hline$R$-squared & 0.9801 & 0.9807 & 0.9805 & 0.9796 & 0.9877 & 0.9821 \\
\hline Adjusted R-squared & 0.9601 & 0.9613 & 0.9608 & 0.9555 & 0.9600 & 0.9592 \\
\hline \multicolumn{7}{|c|}{ Measures of Fit - Dynamic In-sample Prediction } \\
\hline Mean absolute error & 0.0538 & 0.0528 & 0.0537 & 0.0514 & 0.0519 & 0.0514 \\
\hline \multirow{2}{*}{ Root mean squared error } & 0.0678 & 0.0677 & 0.0686 & 0.0643 & 0.0663 & 0.0668 \\
\hline & & & & & & \\
\hline \multirow{2}{*}{$\begin{array}{l}\text { Of Interest } \\
\text { Speed of adjustment }\end{array}$} & $0.3939^{* * *}$ & $0.4019^{* * *}$ & $0.3799^{* * *}$ & $0.4085^{* * *}$ & $0.4989^{* * *}$ & $0.5478^{* * *}$ \\
\hline & $(0.0714)$ & $(0.0654)$ & $(0.0723)$ & $(0.0624)$ & $(0.0703)$ & $(0.0568)$ \\
\hline \multirow[t]{2}{*}{ Long-run elasticity } & $-0.5747^{* *}$ & $-0.9354^{* * *}$ & $-1.2419^{* *}$ & $-0.8338^{* *}$ & $-1.0390^{* * *}$ & $-0.4476^{* *}$ \\
\hline & $(0.2313)$ & $(0.2943)$ & $(0.5316)$ & $(0.3531)$ & $(0.2697)$ & $(0.1796)$ \\
\hline
\end{tabular}


Table 10: Estimation Results - Employment $E_{i, t}$ - High NTE Industries

\begin{tabular}{|c|c|c|c|c|c|c|}
\hline \multirow[t]{2}{*}{ Regressors } & \multicolumn{6}{|c|}{ Specifications } \\
\hline & (1) & (2) & (3) & $(4)$ & (5) & (6) \\
\hline $\ln E_{i, t-1}$ & $\begin{array}{c}0.4387^{* * *} \\
(0.0518)\end{array}$ & $\begin{array}{c}0.4257^{* * *} \\
(0.0492)\end{array}$ & $\begin{array}{c}0.4465^{* * *} \\
(0.0568)\end{array}$ & $\begin{array}{c}0.4462^{* * *} \\
(0.0457)\end{array}$ & $\begin{array}{l}0.3748^{* * *} \\
(0.0422)\end{array}$ & $\begin{array}{l}0.3412^{* * *} \\
(0.0561)\end{array}$ \\
\hline $\ln E_{i, t-2}$ & - & $\begin{array}{l}- \\
-\end{array}$ & - & - & - & $\begin{array}{l}-0.0101 \\
(0.0700)\end{array}$ \\
\hline $\ln w_{i, t}$ & $\begin{array}{c}0.0180 \\
(0.0733)\end{array}$ & $\begin{array}{c}0.1051 \\
(0.0780)\end{array}$ & $\begin{array}{c}0.0657 \\
(0.0871)\end{array}$ & $\begin{array}{c}0.0681 \\
(0.0729)\end{array}$ & $\begin{array}{c}0.0886^{* *} \\
(0.0411)\end{array}$ & $\begin{array}{c}0.1254 \\
(0.0848)\end{array}$ \\
\hline $\ln p_{i, t}^{K}$ & $\begin{array}{c}0.0566^{*} \\
(0.0314)\end{array}$ & $\begin{array}{c}0.0496 \\
(0.0344)\end{array}$ & $\begin{array}{r}0.0516^{*} \\
(0.0332)\end{array}$ & $\begin{array}{c}0.0494^{* *} \\
(0.0204)\end{array}$ & $\begin{array}{c}-0.0397 \\
(0.0285)\end{array}$ & $\begin{array}{c}0.0231 \\
(0.0311)\end{array}$ \\
\hline $\ln p_{i, t-1}^{K}$ & $\begin{array}{l}- \\
-\end{array}$ & - & $\begin{array}{l}- \\
-\end{array}$ & $\begin{array}{l}-0.0041 \\
(0.0196)\end{array}$ & $\begin{array}{l}- \\
-\end{array}$ & $\begin{array}{l}- \\
-\end{array}$ \\
\hline $\ln p_{i, t}^{I I}$ & $\begin{array}{c}0.0379 \\
(0.1416)\end{array}$ & $\begin{array}{l}-0.0784 \\
(0.1702)\end{array}$ & $\begin{array}{c}0.0030 \\
(0.1569)\end{array}$ & $\begin{array}{l}-0.2476 \\
(0.1793)\end{array}$ & $\begin{array}{l}- \\
-\end{array}$ & $\begin{array}{l}-0.1494 \\
(0.1446)\end{array}$ \\
\hline $\ln p_{i, t}^{E}$ & - & $\begin{array}{l}- \\
-\end{array}$ & - & $\begin{array}{l}- \\
-\end{array}$ & $\begin{array}{l}-0.1150 \\
(0.0808)\end{array}$ & $\begin{array}{l}- \\
-\end{array}$ \\
\hline $\ln p_{i, t}^{M}$ & - & - & - & - & $\begin{array}{c}-0.2482^{*} \\
(0.1431)\end{array}$ & $\begin{array}{l}- \\
-\end{array}$ \\
\hline $\ln p_{i, t}^{S}$ & - & - & - & $\begin{array}{l}- \\
-\end{array}$ & $\begin{array}{l}-0.2372^{* * *} \\
(0.0718)\end{array}$ & $\begin{array}{l}- \\
-\end{array}$ \\
\hline $\ln s_{t}$ & $\begin{array}{l}-0.1633 \\
(0.1640)\end{array}$ & - & - & $\begin{array}{l}- \\
-\end{array}$ & $\begin{array}{l}- \\
-\end{array}$ & - \\
\hline $\ln s_{t-1}$ & $\begin{array}{l}- \\
-\end{array}$ & $\begin{array}{l}-0.3817^{*} \\
(0.1997)\end{array}$ & - & $\begin{array}{l}-0.4478^{* *} \\
(0.1789)\end{array}$ & $\begin{array}{l}-0.5692^{* * *} \\
(0.1316)\end{array}$ & $\begin{array}{l}-0.4061^{* * *} \\
(0.1418)\end{array}$ \\
\hline $\ln s_{t}^{m a}$ & $\begin{array}{l}- \\
-\end{array}$ & $\begin{array}{l}- \\
-\end{array}$ & $\begin{array}{l}-0.8131^{* * *} \\
(0.2651)\end{array}$ & $\begin{array}{l}- \\
-\end{array}$ & - & $\begin{array}{l}- \\
-\end{array}$ \\
\hline $\ln Y_{t}$ & $\begin{array}{c}0.2787^{* *} \\
(0.1344)\end{array}$ & $\begin{array}{l}0.2804^{* * *} \\
(0.0959)\end{array}$ & $\begin{array}{l}-0.0571 \\
(0.1614)\end{array}$ & $\begin{array}{l}0.2419^{* * *} \\
(0.0901)\end{array}$ & $\begin{array}{l}0.6977^{* * *} \\
(0.0637)\end{array}$ & $\begin{array}{l}0.3449^{* * *} \\
(0.0708)\end{array}$ \\
\hline CUSFTA $A_{t}$ & $\begin{array}{l}-0.0671^{* *} \\
(0.0294)\end{array}$ & $\begin{array}{l}-0.0492^{*} \\
(0.0287)\end{array}$ & $\begin{array}{l}-0.0408 \\
(0.0250)\end{array}$ & $\begin{array}{l}-0.0421 \\
(0.0261)\end{array}$ & $\begin{array}{l}-0.0666^{* *} \\
(0.0325)\end{array}$ & $\begin{array}{l}-0.0571^{* *} \\
(0.0256)\end{array}$ \\
\hline$N A F T A_{t}$ & $\begin{array}{l}-0.0223 \\
(0.0268)\end{array}$ & $\begin{array}{l}-0.0202 \\
(0.0251)\end{array}$ & $\begin{array}{l}-0.0053 \\
(0.0271)\end{array}$ & $\begin{array}{l}-0.0140 \\
(0.0227)\end{array}$ & $\begin{array}{l}-0.1140^{* * *} \\
(0.0152)\end{array}$ & $\begin{array}{l}-0.0396 * \\
(0.0219)\end{array}$ \\
\hline Measures of Fit - Estiv & ation & & & & & \\
\hline$R$-squared & 0.9485 & 0.9475 & 0.9498 & 0.9495 & 0.9715 & 0.9507 \\
\hline Adjusted $R$-squared & 0.8967 & 0.8947 & 0.8994 & 0.8899 & 0.9074 & 0.8873 \\
\hline Measures of Fit - Dyn & iic In-samp & Prediction & & & & \\
\hline Mean absolute error & 0.0734 & 0.0712 & 0.0735 & 0.0716 & 0.0791 & 0.0717 \\
\hline Root mean squared error & 0.0952 & 0.0934 & 0.0976 & 0.0931 & 0.1060 & 0.0945 \\
\hline $\begin{array}{c}\text { Of Interest } \\
\text { Speed of adjustment }\end{array}$ & $\begin{array}{l}0.5613^{* * *} \\
(0.0518)\end{array}$ & $\begin{array}{l}0.5743^{* * *} \\
(0.0492)\end{array}$ & $\begin{array}{l}0.5535^{* * *} \\
(0.0567)\end{array}$ & $\begin{array}{l}0.5538^{* * *} \\
(0.0457)\end{array}$ & $\begin{array}{l}0.6251^{* * *} \\
(0.0422)\end{array}$ & $\begin{array}{l}0.6689^{* * *} \\
(0.0500)\end{array}$ \\
\hline Long-run elasticity & $\begin{array}{l}-0.2910 \\
(0.2986)\end{array}$ & $\begin{array}{l}-0.6646^{*} \\
(0.3616)\end{array}$ & $\begin{array}{l}-1.4691^{* *} \\
(0.5512)\end{array}$ & $\begin{array}{l}-0.8086^{* *} \\
(0.3484)\end{array}$ & $\begin{array}{l}-0.9106^{* * *} \\
(0.2332)\end{array}$ & $\begin{array}{l}-0.6071^{* *} \\
(0.2301)\end{array}$ \\
\hline
\end{tabular}

From the other side of the ledger, Table 11 reports estimation results for the low-NTE industries in our dataset, once again using the quality-adjusted labour input $L_{i, t}$. Interesting results emerge from this exercise. First, many similarities are present between these results and both their all-industries and high-NTE counterparts. Notably, the coefficients on the lagged labour measures are again highly statistically significant, and so are those on the price of labour and its substitutes, with unchanged signs from before. Such regularities in our basic estimation results helps to establish confidence in the general econometric 
framework.

Table 11: Estimation Results - Labour input $L_{i, t}$ - Low NTE Industries

\begin{tabular}{|c|c|c|c|c|c|c|}
\hline \multirow[t]{2}{*}{ Regressors } & \multicolumn{6}{|c|}{ Specifications } \\
\hline & (1) & (2) & $(3)$ & (4) & (5) & (6) \\
\hline $\ln L_{i, t-1}$ & $\begin{array}{l}0.4760^{* * *} \\
(0.0967)\end{array}$ & $\begin{array}{l}0.4972^{* * *} \\
(0.0875)\end{array}$ & $\begin{array}{l}0.4921^{* * *} \\
(0.1028)\end{array}$ & $\begin{array}{l}0.4396^{* * *} \\
(0.0998)\end{array}$ & $\begin{array}{l}0.3521^{* * *} \\
(0.0963)\end{array}$ & $\begin{array}{c}0.8133^{* * *} \\
(0.1215)\end{array}$ \\
\hline $\ln L_{i, t-2}$ & $\begin{array}{l}- \\
-\end{array}$ & - & - & - & $\begin{array}{l}- \\
-\end{array}$ & $\begin{array}{l}-0.3359^{* * *} \\
(0.0815)\end{array}$ \\
\hline $\ln w_{i, t}$ & $\begin{array}{l}-0.2121^{* * *} \\
(0.0498)\end{array}$ & $\begin{array}{l}-0.2253^{* * *} \\
(0.0578)\end{array}$ & $\begin{array}{l}-0.2319^{* * *} \\
(0.0483)\end{array}$ & $\begin{array}{l}-0.2134^{* * *} \\
(0.0514)\end{array}$ & $\begin{array}{l}-0.1900^{* * *} \\
(0.0614)\end{array}$ & $\begin{array}{l}-0.2645^{* * *} \\
(0.0551)\end{array}$ \\
\hline $\ln p_{i, t}^{K}$ & $\begin{array}{l}0.0570^{* * *} \\
(0.0128)\end{array}$ & $\begin{array}{l}0.0576^{* * *} \\
(0.0135)\end{array}$ & $\begin{array}{l}0.0558^{* * *} \\
(0.0126)\end{array}$ & $\begin{array}{l}0.0374^{* * *} \\
(0.0093)\end{array}$ & $\begin{array}{l}0.0697^{* * *} \\
(0.0152)\end{array}$ & $\begin{array}{c}0.0258^{*} \\
(0.0148)\end{array}$ \\
\hline $\ln p_{i, t-1}^{K}$ & - & - & - & $\begin{array}{l}0.0329^{* * *} \\
(0.0112)\end{array}$ & $\begin{array}{l}- \\
-\end{array}$ & - \\
\hline $\ln p_{i, t}^{I I}$ & $\begin{array}{l}0.2807^{* * *} \\
(0.0779)\end{array}$ & $\begin{array}{l}0.2642^{* * *} \\
(0.0615)\end{array}$ & $\begin{array}{l}0.2714^{* * *} \\
(0.0751)\end{array}$ & $\begin{array}{l}0.2989^{* * *} \\
(0.0557)\end{array}$ & - & $\begin{array}{l}0.2803^{* * *} \\
(0.0574)\end{array}$ \\
\hline $\ln p_{i, t}^{E}$ & - & $\begin{array}{l}- \\
-\end{array}$ & - & - & $\begin{array}{c}-0.0970^{*} \\
(0.0541)\end{array}$ & $\begin{array}{l}- \\
-\end{array}$ \\
\hline $\ln p_{i, t}^{M}$ & $\begin{array}{l}- \\
-\end{array}$ & $\begin{array}{l}- \\
-\end{array}$ & $\begin{array}{l}- \\
-\end{array}$ & - & $\begin{array}{l}0.2063^{* * *} \\
(0.0525)\end{array}$ & $\begin{array}{l}- \\
-\end{array}$ \\
\hline $\ln p_{i, t}^{S}$ & - & - & - & - & $\begin{array}{l}-0.2665^{* *} \\
(0.1086)\end{array}$ & - \\
\hline $\ln s_{t}$ & $\begin{array}{c}0.0433 \\
(0.0732)\end{array}$ & $\begin{array}{l}- \\
-\end{array}$ & - & - & $\begin{array}{l}- \\
-\end{array}$ & - \\
\hline $\ln s_{t-1}$ & $\begin{array}{l}- \\
-\end{array}$ & $\begin{array}{l}-0.0426 \\
(0.0554)\end{array}$ & $\begin{array}{l}- \\
-\end{array}$ & $\begin{array}{l}-0.0595 \\
(0.0511)\end{array}$ & $\begin{array}{c}-0.0625 \\
(0.1761)\end{array}$ & $\begin{array}{c}0.0690 \\
(0.0663)\end{array}$ \\
\hline $\ln s_{t}^{m a}$ & $\begin{array}{l}- \\
-\end{array}$ & $\begin{array}{l}- \\
-\end{array}$ & $\begin{array}{c}0.0445 \\
(0.1529)\end{array}$ & - & - & - \\
\hline $\ln Y_{t}$ & $\begin{array}{l}-0.0196 \\
(0.0544)\end{array}$ & $\begin{array}{l}-0.0778 \\
(0.0884)\end{array}$ & $\begin{array}{l}-0.0220 \\
(0.0776)\end{array}$ & $\begin{array}{l}-0.0953 \\
(0.0808)\end{array}$ & $\begin{array}{l}-0.2516 \\
(0.1902)\end{array}$ & $\begin{array}{l}-0.0746 \\
(0.0777)\end{array}$ \\
\hline$C U S F T A_{t}$ & $\begin{array}{c}0.0095 \\
(0.0072)\end{array}$ & $\begin{array}{c}0.0110 \\
(0.0082)\end{array}$ & $\begin{array}{c}0.0079 \\
(0.0080)\end{array}$ & $\begin{array}{c}0.0098 \\
(0.0075)\end{array}$ & $\begin{array}{c}0.0193 \\
(0.0173)\end{array}$ & $\begin{array}{l}-0.0038 \\
(0.0064)\end{array}$ \\
\hline$N A F T A_{t}$ & $\begin{array}{l}-0.0353^{* * *} \\
(0.0117)\end{array}$ & $\begin{array}{l}-0.0315^{* *} \\
(0.0130)\end{array}$ & $\begin{array}{l}-0.0373^{* * *} \\
(0.0124)\end{array}$ & $\begin{array}{l}-0.0276^{* *} \\
(0.0137)\end{array}$ & $\begin{array}{l}-0.0413^{* *} \\
(0.0169)\end{array}$ & $\begin{array}{l}-0.0422^{\text {*** }} \\
(0.0118)\end{array}$ \\
\hline Measures of Fit - Estin & ation & & & & & \\
\hline $\begin{array}{l}R \text {-squared } \\
\text { Adjusted R-squared }\end{array}$ & $\begin{array}{l}0.9526 \\
0.8910\end{array}$ & $\begin{array}{l}0.9521 \\
0.8986\end{array}$ & $\begin{array}{l}0.9525 \\
0.8993\end{array}$ & $\begin{array}{l}0.9520 \\
0.8881\end{array}$ & $\begin{array}{l}0.9650 \\
0.8719\end{array}$ & $\begin{array}{l}0.9564 \\
0.8928\end{array}$ \\
\hline $\begin{array}{l}\text { Measures of Fit - Dyn } \\
\text { Mean absolute error }\end{array}$ & $\begin{array}{l}\text { nic In-sampl } \\
0.0513\end{array}$ & $\begin{array}{l}\text { Prediction } \\
0.0505\end{array}$ & 0.0512 & 0.0502 & 0.0534 & 0.0586 \\
\hline Root mean squared error & 0.0754 & 0.0742 & 0.0752 & 0.0733 & 0.0735 & 0.0862 \\
\hline $\begin{array}{c}\text { Of Interest } \\
\text { Speed of adjustment }\end{array}$ & $\begin{array}{l}0.5240^{* * *} \\
(0.0967)\end{array}$ & $\begin{array}{l}0.5028^{* * *} \\
(0.0875)\end{array}$ & $\begin{array}{l}0.5079^{* * *} \\
(0.1028)\end{array}$ & $\begin{array}{l}0.5604^{* * *} \\
(0.0998)\end{array}$ & $\begin{array}{l}0.6479^{* * *} \\
(0.0963)\end{array}$ & $\begin{array}{l}0.5226^{* * *} \\
(0.0971)\end{array}$ \\
\hline Long-run elasticity & $\begin{array}{c}0.0826 \\
(0.1312)\end{array}$ & $\begin{array}{l}-0.0847 \\
(0.1160)\end{array}$ & $\begin{array}{c}0.0876 \\
(0.2911)\end{array}$ & $\begin{array}{l}-0.1061 \\
(0.0929)\end{array}$ & $\begin{array}{l}-0.0964 \\
(0.2687)\end{array}$ & $\begin{array}{c}0.1320 \\
(0.1201)\end{array}$ \\
\hline
\end{tabular}

However, the numerical estimates also depict interesting quantitative differences. Notably, the speed of adjustment is faster than previously estimated, the own-price elasticity is much stronger, and the effects of world GDP and the exchange rate are both much muted and often not statistically significant. Overall, Table 11 paints a picture of industries reacting more rapidly to home-grown factors like wages, and much less to foreign influences, as expected from industries relying less on international trade. Using hours $H_{i, t}$ instead of $L_{i, t}$ uncovers 
similar results. Meanwhile using employment $E_{i, t}$ confirms the contrast already established above, with employment adjusting faster than hours, suggesting a countercyclical patterns for hours per worker. ${ }^{16}$

\section{Conclusion}

Hours worked and employment in Canada's manufacturing industries have evolved through a pattern of boom-bust cycles in the last three decades. We present evidence that this boom-bust pattern is strongly to fluctuations in the exchange rate of the Canadian dollar. Our econometric strategy employs panel data estimation techniques and carefully control for the unit roots, cointegration and cross-section dependence characteristics of the data. Our results suggest that a $10 \%$ appreciation of the Canadian dollar can decrease hours worked and employment by around $7 \%$ and that this effect occurs relatively rapidly, with about $40 \%$ of the gap between realized and targeted labour being closed every year. We also find that the GDPs of Canada's trading partners have important effects on Canadian manufacturing employment. In addition, we report that enactment of two major trade agreements, between Canada and the United States in 1989 and between Canada, the United States and Mexico in 1994 have had a sizeable negative impact on hours and employment in Canada's manufacturing industries. Finally, our results indicate that our results are stronger for industries with above-average net trade exposure, and that employment responds faster than hours worked to shocks, suggesting that hours per employed person adjust in countercyclical patterns.

Our estimations track the evolution of the labour input well, as illustrated by Figure 2 . The figure plots the observed and predicted values of the labour input in the all-industries case. ${ }^{17}$ While the fit of our estimations is excellent overall, predicted hours lag somewhat the turning points, missing the beginning of the recovery in the late 1990s by one year and then the 2000 peak. By contrast, predicted employment anticipates the turning points, notably in 1990 and again in $1993 .{ }^{18}$ This raises the interesting possibility that a combination of

\footnotetext{
${ }^{16}$ These last tables of results are not reported to streamline the presentation but are available from the authors.

${ }^{17}$ The specification chosen uses the lagged value of the exchange rate, i.e. column (2) in the tables presenting our estimation results. Predicted labour is generated recursively by the model for each year, with the initial year in our sample (1976) serving as the initial condition. This recursive method implies that the actual lagged labour input is never used to generate the predictions.

${ }^{18} \mathrm{~A}$ similar pattern is present when the fit of the high-NTE industries is analyzed. This figure is not reported to streamline the presentation but is available from the authors
} 
the forecasts from both specification be able to correctly signal turning points. Overall, our empirical results illuminate the deep impacts that external factors have on manufacturing industries in Canada and their labour input decisions. These results are timely, as the recent renewed appreciation of the Canadian dollar has revived interest about the future evolution of Canada's manufacturing industries. 


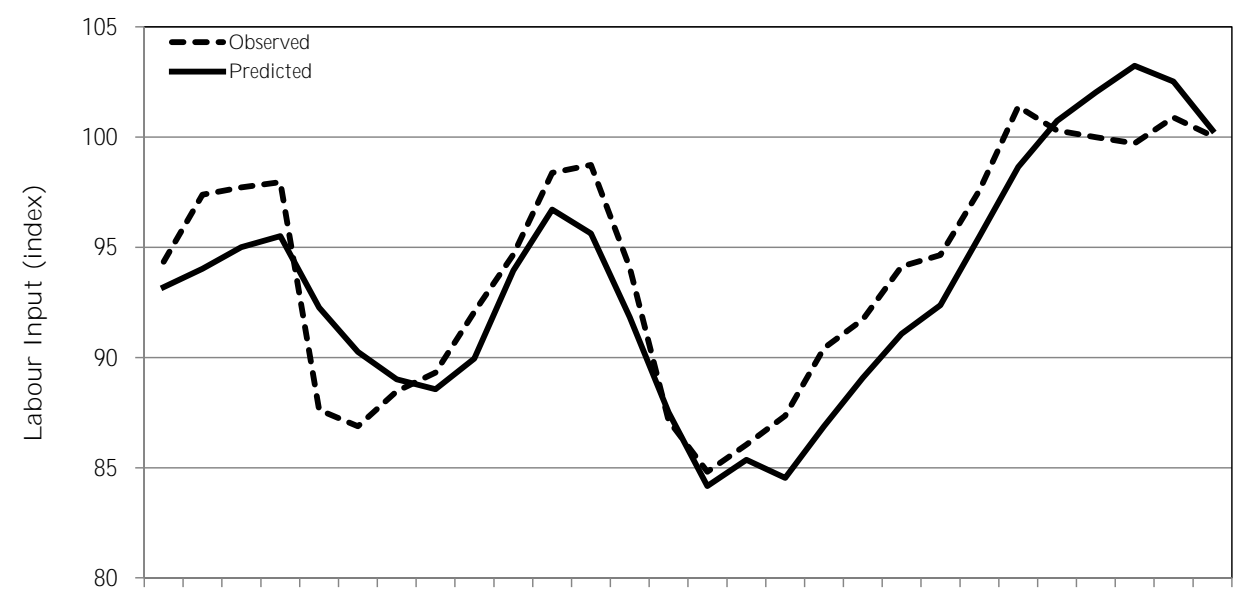

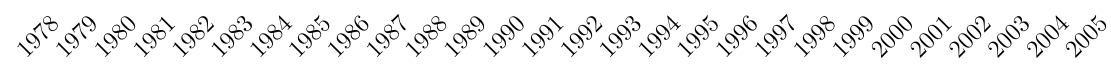

(a)

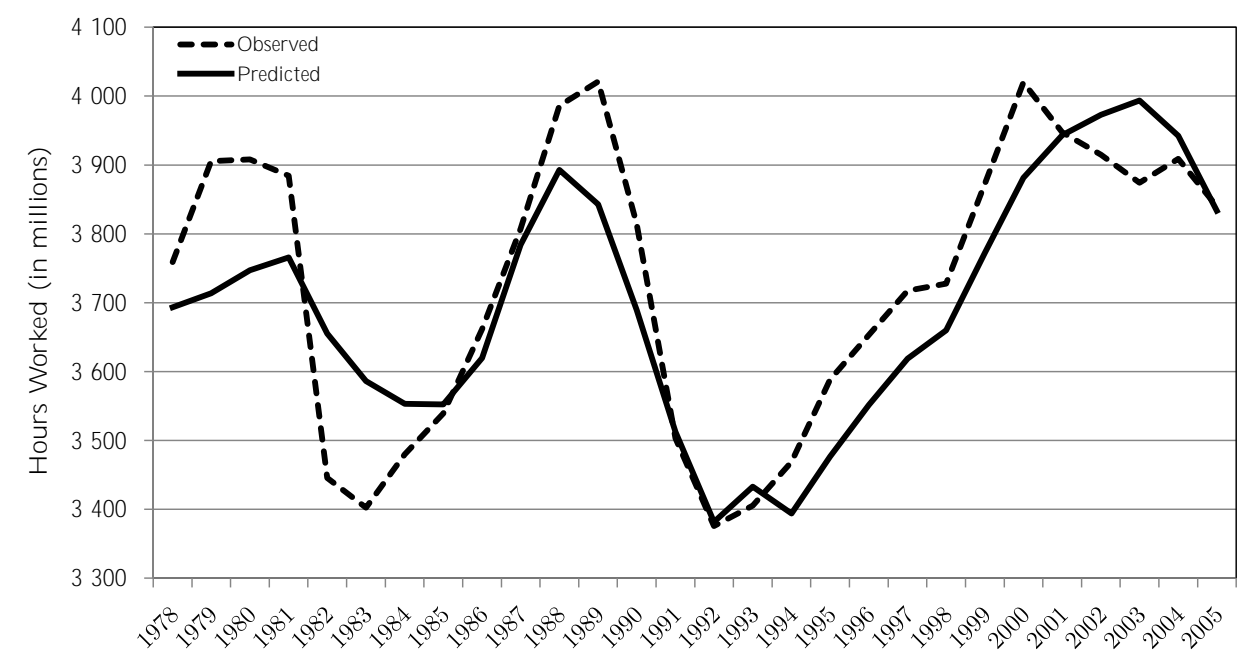

(b)

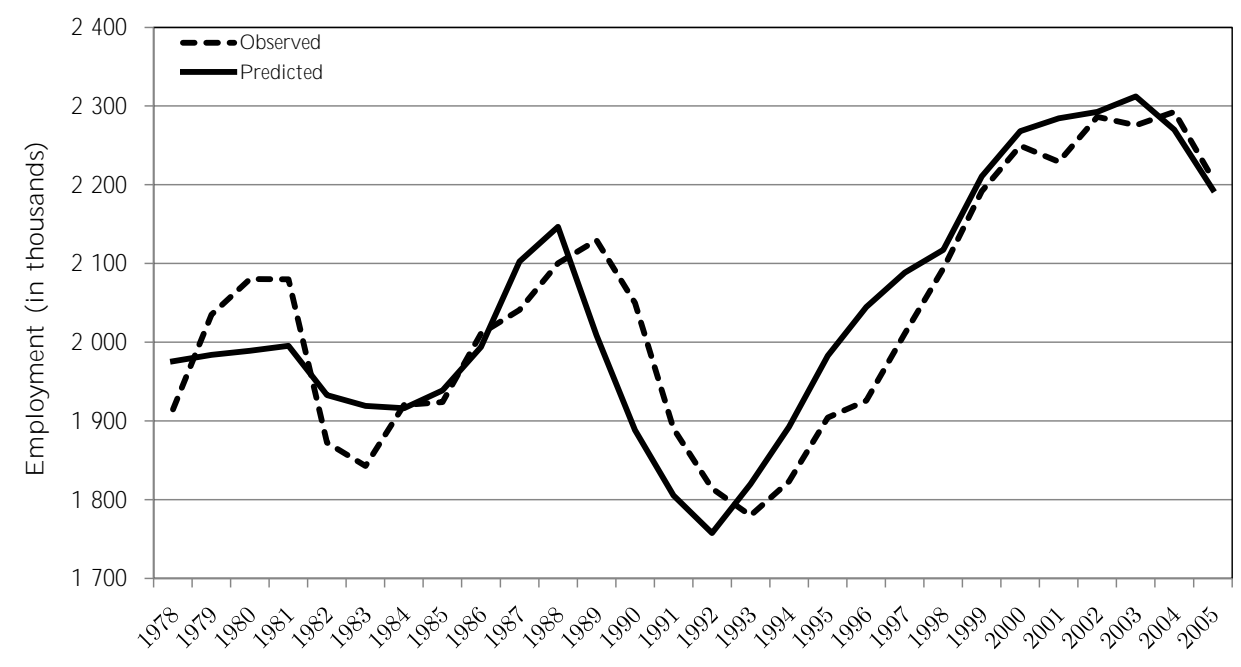

(c)

Figure 2: Dynamic In-Sample Prediction, All Manufacturing Industries, from 1976 to 2005. 


\section{References}

Beaulieu, E. (2000): "The Canada-U.S. Free Trade Agreement and labour market adjustment in Canada," Canadian Journal of Economics, 33(2), 540-563.

Burgess, S. M., And M. M. Knetter (1998): "An international comparison of employment adjustment to exchange rate fluctuations," Review of International Economics, 6(1), 151-63.

Campa, J. M., and L. S. Goldberg (2001): "Employment versus wage adjustment and the U.S. dollar," The Review of Economics and Statistics, 83(3), 477-489.

Chang, Y., J. Y. PARK, And K. Song (2006): "Bootstrapping cointegrating regressions," Journal of Econometrics, 133(2), 703-739.

Dekle, R. (1998): "The yen and Japanese manufacturing employment," Journal of International Money and Finance, 17(5), 785-801.

Di Iorio, F., AND S. FACHIN (2009): "A residual-based bootstrap test for panel cointegration," Economics Bulletin, 29(4), 3222-3232.

Dion, R. (2000): "Trends in Canada's merchandise trade," Bank of Canada Review, 2000(Winter), 29-41.

Driscoll, J. C., And A. C. KraAy (1998): "Consistent covariance matrix estimation with spatially dependent panel data," The Review of Economics and Statistics, 80(4), $549-560$.

FACHIN, S. (2007): "Long-run trends in internal migrations in italy: a study in panel cointegration with dependent units," Journal of Applied Econometrics, 22(2), 401-428.

Gaston, N., And D. Trefler (1997): "The labour market consequences of the CanadaU.S. Free Trade Agreement," Canadian Journal of Economics, 30(1), 18-41.

Im, K. S., M. H. Pesaran, and Y. Shin (2003): "Testing for unit roots in heterogeneous panels," Journal of Econometrics, 115(1), 53-74.

KAO, C. (1999): "Spurious regression and residual-based tests for cointegration in panel data," Journal of Econometrics, 90(1), 1-44. 
KaO, C., And B. Chen (1995): "On the estimation and inference for cointegration in panel data when the cross section and time series dimensions are comparable," Manuscript, Center for Policy Research.

KaO, C., And M.-H. Chiang (1999): "On the Estimation and Inference of a Cointegrated Regression in Panel Data," Center for Policy Research Working Papers 2, Center for Policy Research, Maxwell School, Syracuse University.

Lafrance, R., P. Osakwe, and P. St-Amant (1998): "Evaluating alternative measures of the real effective exchange rate," Working Papers 98-20, Bank of Canada.

Leung, D., And T. Yuen (2007): "Labour Market Adjustments to Exchange Rate Fluctuations: Evidence from Canadian Manufacturing Industries," Open Economies Review, 18(2), 177-189.

Li, H., ANd G. S. Maddala (1997): "Bootstrapping cointegrating regressions," Journal of Econometrics, 80(2), 297-318.

Li, H., And Z. XiaO (2003): "Bootstrapping cointegrating regressions using blockwise bootstrap methods," Journal of Statistical Computation and Simulation, 73(11), 775789.

Mark, N. C., ANd D. Sul (2002): "Cointegration vector estimation by panel DOLS and long-run money demand," NBER Technical Working Papers 0287, National Bureau of Economic Research, Inc.

Moon, H. R., And B. Perron (2004): "Testing for a unit root in panels with dynamic factors," Journal of Econometrics, 122(1), 81-126.

NG, S., And P. Perron (2001): "Lag length selection and the construction of unit root tests with good size and power," Econometrica, 69(6), 1519-1554.

Nickell, S. (1987): "Dynamic models of labour demand," in Handbook of Labor Economics, ed. by O. Ashenfelter, and R. Layard, vol. 1 of Handbook of Labor Economics, chap. 9, pp. 473-522. Elsevier.

Paparoditis, E., And D. N. Politis (2001): "Unit root testing via the continuous-path 
block bootstrap," University of California at San Diego, Economics Working Paper Series 2001-06, Department of Economics, UC San Diego.

_ (2003): "Residual-based block bootstrap for unit root testing," Econometrica, $71(3), 813-855$.

Parker, C., E. Paparoditis, and D. N. Politis (2006): "Unit root testing via the stationary bootstrap," Journal of Econometrics, 133(2), 601-638.

Pedroni, P. (1996): "Fully modified OLS for heterogeneous cointegrated panels and the case of purchasing power parity ," Working paper in economics, Indiana University.

Pesaran, M. H. (2004): "General diagnostic tests for cross section dependence in panels," IZA Discussion Papers 1240, Institute for the Study of Labor (IZA).

(2007): "A simple panel unit root test in the presence of cross-section dependence," Journal of Applied Econometrics, 22(2), 265-312.

Phillips, P. C. B., And B. E. Hansen (1990): "Statistical inference in instrumental variables regression with I(1) processes," Review of Economic Studies, 57(1), 99-125.

Phillips, P. C. B., And H. R. Moon (2000): "Nonstationary panel data analysis: an overview of some recent developments," Econometric Reviews, 19(3), 263-286.

Phillips, P. C. B., And D. Sul (2003): "Dynamic panel estimation and homogeneity testing under cross section dependence," Econometrics Journal, 6(1), 217-259.

Politis, D. N., And J. Romano (1994): "The stationary bootstrap," Journal of American Statististical Association, 89, 1303-1313.

SAikkonen, P. (1991): "Asymptotically Efficient Estimation of Cointegration Regressions," Econometrica, 7(1), 1-21.

Stock, J. H., And M. W. Watson (1993): "A simple estimator of cointegrating vectors in higher order integrated systems," Econometrica, 61(4), 783-820.

Westerlund, J., And D. L. Edgerton (2007): "A panel bootstrap cointegration test," Economics Letters, 97(3), 185-190. 


\section{Appendices}

\section{A Definitions and Data Sources}

\section{A.1 Industry-Specific Data - KLEMS}

Labour input $\left(L_{i, t}\right)$

1976 to 2005 data

Labour input by manufacturing industries at the NAICS 3-digit level. This index is obtained by chained-Fisher aggregation of hours worked of all workers, classified by education, work experience, and class of workers (paid workers versus self-employed and unpaid family workers) using hourly compensation as weights.

Source: Statistics Canada (Cansim Table 383-0022), Internal Calculations

Hours worked $\left(H_{i, t}\right)$

1976 to 2005 data

Hours worked by manufacturing industries at the NAICS 3-digit level. The number of hours worked in all jobs is the number of all jobs times the annual average hours worked in all jobs. According to the retained definition, hours worked means the total number of hours that a person spends working, whether paid or not. In general, this includes regular and overtime hours, breaks, travel time, training in the workplace and time lost in brief work stoppages where workers remain at their posts. On the other hand, time lost due to strikes, lockouts, annual vacation, public holidays, sick leave, maternity leave or leave for personal needs are not included in total hours worked.

Source: Statistics Canada (Cansim Table 383-0022), Internal Calculations

\section{Relative price of labour $\left(w_{i, t}\right)$}

1976 to 2005 data

Chained Fisher index of prices calculated as the ratio of the labour compensation index to the Fisher volume index of labour input deflated by the industrial product price index by manufacturing industries at the NAICS 3-digit level. Labour compensation consists of all payments in cash or in kind made by domestic producers to workers for services rendered - in other words, total payroll. It includes the salaries and supplementary labour income of paid 
workers, plus an imputed labour income for self-employed workers. The Industrial Product Price Index (IPPI) measures price changes for major commodities sold by manufacturers in Canada. The prices collected are for goods sold at the factory gate. As a result, the prices covered by the IPPI refer not to what a purchaser pays but to what the producer receives. They exclude all indirect taxes, such as sales taxes and tariffs as this money does not go to the factors of production (i.e. labour, capital, or profit). They also exclude any transportation service performed by a common carrier beyond the factory gate and any distribution services performed by the retail or wholesale trade industries.

Source: Statistics Canada (Cansim Tables 329-0038 and 383-0022), Internal Calculations

\section{Relative price of capital $\left(p_{i, t}^{K}\right)$}

1976 to 2005 data

Chained Fisher index of prices calculated as the ratio of capital cost index to the Fisher volume index of capital input deflated by the industrial product price index by manufacturing industries at the NAICS 3-digit level. Capital cost represents the surplus-profits, depreciation, rent, and net interest-intended as compensation to the owners of capital. It is calculated as nominal gross domestic product (GDP) at basic prices minus labour compensation.

Source: Statistics Canada (Cansim Tables 329-0038 and 383-0022), Internal Calculations

\section{Relative price of intermediate inputs $\left(p_{i, t}^{I I}\right)$}

1976 to 2005 data

Chained Fisher index of prices calculated as the ratio of the intermediate inputs cost index to the Fisher volume index of intermediate inputs by manufacturing industries deflated by the industrial product price index by manufacturing industries at the NAICS 3-digit level. Source: Statistics Canada (Cansim Tables 329-0038 and 383-0022), Internal Calculations

\section{Relative price of energy $\left(p_{i, t}^{E}\right)$}

1976 to 2005 data

Chained Fisher index of prices calculated as the ratio of energy cost index to the Fisher volume index of energy input by manufacturing industries deflated by the industrial product price index by manufacturing industries at the NAICS 3-digit level.

Source: Statistics Canada (Cansim Tables 329-0038 and 383-0022), Internal Calculations 
Relative price of materials $\left(p_{i, t}^{M}\right)$

1976 to 2005 data

Chained Fisher index of prices calculated as the ratio of the materials cost index to the Fisher volume index of materials input deflated by the industrial product price index by manufacturing industries at the NAICS 3-digit level.

Source: Statistics Canada (Cansim Tables 329-0038 and 383-0022), Internal Calculations

Relative price of services $\left(p_{i, t}^{S}\right)$

1976 to 2005 data

Chained Fisher index of prices calculated as the ratio of the cost of services index to the Fisher volume index of services input deflated by the industrial product price index by manufacturing industries at the NAICS 3-digit level.

Source: Statistics Canada (Cansim Tables 329-0038 and 383-0022), Internal Calculations

\section{A.2 Industry-Specific Data - Labour Force Survey}

Employment $\left(E_{i, t}\right)$

1976 to 2005 data

Total employment (full- and part-time) by manufacturing industries at the NAICS 3-digit level based on the Labour Force Survey 2007.

Source: Statistics Canada (Labour Force Survey), Internal Calculations

\section{A.3 Aggregate Data}

\section{Real effective exchange rate $\left(s_{t}\right)$}

1976 to 2005 data

Nominal exchange rate between Canada and its major trade partners, weighted by their respective shares in Canada's international trade and deflated by normalized unit labour costs (NULC). Unit labour costs (ULC) indices are the ratio of the cost of a unit of labour to its productivity, and are often used as indicators of international competitiveness, by measuring a country's ability to sell its products in international markets. Since the measured productivity of labour can exhibit wide swings in the course of the business cycle, notably through labour hoarding in downturns, the literature has found it preferable to correct for cyclical effects and use "normalized" unit labour costs, often through the use of 
the Hodrick-Prescott filter.

Source: IMF

World trade-weighted real gross domestic product $\left(Y_{t}\right)$

1976 to 2005 data

We construct a World, Trade-Weighted GDP measure by adding Canadian GDP to a weighted sum of the GDPs of its major trade partners, where the weights reflect the share of their respective trade with Canada.

Source: Strategis (Industry Canada), IMF World Economic Outlook Database (April 2008), Internal Calculations

CUSFTA dummy $\left(C U S F T A_{t}\right)$

1976 to 2005 data

A dummy variable that takes the value 1 beginning on and after 1989 and 0 before 1989, to signal the enactment of the Canada-U.S. Free Trade Agreement.

NAFTA dummy $\left(N A F T A_{t}\right)$

1976 to 2005 data

A Dummy variable that takes the value 1 beginning on and after 1994 and 0 before 1994, to signal the enactment of the North-American Free Trade Agreement. 


\section{B Industry Classification by Net Exposure to International Trade}

Table 12: List of Industries by Type of Net Exposure to International Trade, by NAICS Code

\begin{tabular}{lll}
\hline \hline NAICS & Manufacturing Industries & NTE \\
\hline 311 & Food & Low \\
312 & Beverage and tobacco product & Low \\
$313 \& 314$ & Textile mills \& Textile product mills & High \\
315 & Clothing & High \\
316 & Leather and allied product & High \\
321 & Wood product & High \\
322 & Paper & High \\
323 & Printing and related support activities & Low \\
324 & Petroleum and coal product & Low \\
325 & Chemical & High \\
326 & Plastics and rubber product & High \\
327 & Non-metallic mineral product & Low \\
331 & Primary metal & Low \\
332 & Fabricated metal product & High \\
333 & Machinery & High \\
334 & Computer and electronic product & High \\
335 & Electrical equipment, appliance and component & High \\
336 & Transportation & High \\
337 & Furniture and related product & High \\
339 & Miscellaneous & High \\
\hline \hline
\end{tabular}

